Article

\title{
Physiological and Epigenetic Reaction of Barley (Hordeum vulgare L.) to the Foliar Application of Silicon under Soil Salinity Conditions
}

\author{
Barbara Stadnik $^{1, *}$, Renata Tobiasz-Salach ${ }^{1}\left(\mathbb{D}\right.$ and Marzena Mazurek ${ }^{2}$ (D) \\ 1 Department of Crop Production, University of Rzeszow, Zelwerowicza 4, 35-601 Rzeszow, Poland; \\ rtobiasz@ur.edu.pl \\ 2 Department of Physiology and Plant Biotechnology, University of Rzeszow, Ćwiklińskiej 2, \\ 35-601 Rzeszow, Poland; marzena.guty@poczta.onet.pl \\ * Correspondence: bajda1493@gmail.com
}

check for updates

Citation: Stadnik, B.; Tobiasz-Salach, R.; Mazurek, M. Physiological and Epigenetic Reaction of Barley (Hordeum vulgare L.) to the Foliar Application of Silicon under Soil Salinity Conditions. Int. J. Mol. Sci. 2022, 23, 1149. https://doi.org/ $10.3390 /$ ijms 23031149

Academic Editors: Yong Li and Richard T. Sayre

Received: 30 December 2021

Accepted: 18 January 2022

Published: 21 January 2022

Publisher's Note: MDPI stays neutral with regard to jurisdictional claims in published maps and institutional affiliations.

Copyright: (c) 2022 by the authors. Licensee MDPI, Basel, Switzerland. This article is an open access article distributed under the terms and conditions of the Creative Commons Attribution (CC BY) license (https:/ / creativecommons.org/licenses/by/ $4.0 /)$.

\begin{abstract}
Soil salinity is an important environmental factor affecting physiological processes in plants. It is possible to limit the negative effects of salt through the exogenous application of microelements. Silicon ( $\mathrm{Si}$ ) is widely recognized as an element improving plant resistance to abiotic and biotic stresses. The aim of the research was to determine the impact of foliar application of Si on the photosynthetic apparatus, gas exchange and DNA methylation of barley (Hordeum vulgare L.) grown under salt stress. Plants grown under controlled pot experiment were exposed to sodium chloride $(\mathrm{NaCl})$ in the soil at a concentration of $200 \mathrm{mM}$, and two foliar applications of Si were made at three concentrations $(0.05 \%, 0.1 \%$ and $0.2 \%)$. Measurements were made of relative chlorophyll content in leaves $(\mathrm{CCl})$, gas exchange parameters $\left(C_{i}, E, g_{s}\right.$, and $\left.P_{N}\right)$, and selected chlorophyll fluorescence parameters $\left(F_{v} / F_{m}\right.$, $\mathrm{F}_{\mathrm{V}} / \mathrm{F}_{0}$, PI and RC/ABS). Additionally, DNA methylation level based on cytosine methylation within the $3^{\prime}$ CCGG $5^{\prime}$ sequence was analyzed. Salinity had a negative effect on the values of the parameters examined. Exogenous application of Si by spraying leaves increased the values of the measured parameters in plants. Plants treated with $\mathrm{NaCl}$ in combination with the moderate $(0.1 \%)$ and highest $(0.2 \%)$ dose of Si indicated the lowest methylation level. Decrease of methylation implicated with activation of gene expression resulted in better physiological parameters observed in this group of barley plants.
\end{abstract}

Keywords: chlorophyll fluorescence; gas exchange; methylation-sensitive amplified polymorphism (MSAP); plant stress

\section{Introduction}

The primary role of agriculture is to provide food for both humans and animals. The growing world population and the simultaneous constant shrinkage of resources of arable land suitable for food production poses a number of challenges to modern agriculture. At the same time, soils with increased salt content exist in more than 100 countries, and their global area is approximately 1 billion hectares. In total $20 \%$ of cultivated land in the world, and 33\% of irrigated land, are salt-affected and degraded [1-3]. Excessive soil salinity affects the availability and supply of soil nutrients to crops and reduces the productivity, the size and quality of the agricultural crop, which is considered to be one of the world's most important challenges for agricultural production, food security and sustainability [1,4-6]. It is estimated that salinity can reduce yields of all important crops by $20 \%$ to $50 \%[7,8]$. The high level of salt in the soil causes two types of stressful situations in plants: osmotic stress and disruption of ion homeostasis [9-11]. As a result of osmotic stress, a number of changes occur in plants, leading to an increase in the level of reactive oxygen species (ROS) and the occurrence of oxidative stress [12-17]. Plants produce ROS (the singlet oxygen $\left(\mathrm{O}_{2}\right)$, superoxide $\left(\mathrm{O}^{2-}\right)$, hydrogen peroxide $\left(\mathrm{H}_{2} \mathrm{O}_{2}\right)$ and hydroxyl radical 
$\left(\mathrm{HO}^{\bullet}\right)$ in chloroplasts, mitochondria, peroxisomes and other sites of the cell because of their metabolic processes such as respiration and photosynthesis [18-20]. Photosynthesis is one of the most important processes seriously affected by environmental stress. Abiotic stress causes an excessive reduction in the electron transport chain (ETC), which in turn leads to photooxidation [21]. High salt levels inhibit the activity of the enzymes involved in photosynthesis and has an impact on the proteins involved in both the light and dark phases of photosynthesis. Exposure to salinity also causes a decrease in Rubisco activity and affects $\mathrm{CO}_{2}$ binding [22-24]. Crop plants induce a complex and unique cellular and molecular response to various stresses to prevent damage and ensure cell survival [6,25-31]. One of the earliest plant responses to many abiotic stresses is a change in the level of abscisic acid (ABA) [32]. Greater accumulation of ABA promotes a signalling cascade in guard cells, leading to the release of $\mathrm{K}^{+}$ions from guard cells, which results in a reduction in turgor pressure, and then stomatal closure $[33,34]$. Chlorophyll fluorescence analysis has become one of the most powerful and widely used techniques in plant physiology and is an easy and sensitive method used as an indicator of stress response in plants. It plays an important role in understanding the basic mechanisms of photosynthesis, plant response to environmental change, genetic variability and ecological diversity [35-38].

Epigenetic mechanisms provide an adaptive layer of control in the regulation of gene expression that enables an organism to adjust to a changing environment. Epigenetic regulation increases the functional complexity of deoxyribonucleic acid (DNA) by altering chromatin structure, nuclear organization, and transcript stability [39]. DNA methylation is known to play an important role in epigenetic mechanisms of the regulation of gene expression in eukaryotes [40]. DNA methylation influences the ability of transcription factors and other DNA-binding proteins to recognize a nucleotide sequence that regulates gene expression. This process is associated with repression of gene transcription [41]. Changes in the methylation patterns of DNA during a cell's lifetime provide an adaptive ability for the organism to adjust to changes in the environment [39-43].

Methylation-sensitive amplified polymorphism (MSAP) is a powerful technique for studying the genome methylation status. It is a modification of the AFLP technique in which isoschizomers, MspI and HpaII, are employed as 'frequent-cutter'. Both MspI and HpaII recognize the same restriction site $\left(5^{\prime} \mathrm{CCGG} 3^{\prime}\right)$, but show differential sensitivity to DNA methylation $[40,44]$. This technique has been applied to study the impact of stress on the level and pattern of DNA methylation in rice [45-47], wheat [48], cotton [49] or soybean [50]. Differential DNA methylation patterns and polymorphism among stressresistant and stress-sensitive plants suggest the possibility of involvement of these distinct DNA fragments in the regulation of physiological processes and morphological traits, enabling adjustment to changing environment conditions [45].

Barley (Hordeum vulgare L.) is the most salinity-tolerant species among the cereals, but it reacts negatively at higher concentrations [10]. Due to increasing salinity problems in the world and the negative effects of high salt levels on plants, we must find effective ways to increase the resistance of crop species. The foliar application of micronutrients seems to be the one of the methods of reducing the negative impact of salt stress on plants. Numerous studies conducted on many species of crops have proven the effectiveness of this method of application in creating plant resistance to environmental stresses such as high temperature, drought, salinity, and excess water [51-54]. The use of micronutrients increases the metabolism of antioxidants in plants [52,55-57]. One of the elements that can be used as an alternative method of increasing plant resistance is silicon ( $\mathrm{Si}$ ). Many plants, especially monocotyledons, including barley, contain large amounts of $\mathrm{Si}-$ up to $10 \%$ dry mass $[58,59]$. Despite the large accumulation of Si in plants, it has so far not been considered an essential element for higher plants. However, it has a beneficial effect on the growth of many species. Si has a role as a messenger by binding to the hydroxyl groups of proteins involved in cell signalling. Si also has a mechanical effect providing protection to the plant thanks to its deposition in plant tissues [60]. The absorption of toxic ions by the roots is also reduced by Si supply [61]. Many authors have obtained results indicating an important role 
of silicon in determining the resistance of cereal crops [62-68]. This element has the ability to strengthen plant defense systems in response to abiotic stresses by increasing the activity of important antioxidant enzymes such as superoxide dismutase (SOD), catalase (CAT) and peroxidase (POD) $[56,69,70]$. Scientific research shows that silicon is clearly beneficial due to its role in improving the photosynthesis of plants grown under stress conditions [71-74]. Si can be taken up by both the roots and leaves of plants. Studies prove that foliar application is highly effective, and its positive aspects should also be emphasized-this method of application is cheaper and more convenient to use than soil fertilization. The justification for feeding plants by application of liquid fertilizer containing silicon compounds directly to the leaves also exists because this element is not taken easily by the roots, e.g., in drought or saline conditions [75-79]. Spraying with silicon compounds can have a positive effect on the growth and yield of plants and reduce biotic and abiotic stress, as well as the negative impact of heavy metals on plants [67,80-83]. Research on silicon and its importance for individual species should be extended due to the number of positive impacts of this element on plants, in particular by increasing resistance to environmental stresses. There are few reports concerning the optimal dose of silicon supplied via foliar application for plants grown under salt stress [84-87], therefore research was carried out to determine the effect of foliar application of different concentrations of silicon on the activity of the photosynthetic apparatus, gas exchange and the DNA methylation level in barley (Hordeum vulgare L.) grown under salt stress conditions. The scientific hypothesis of the study assumes that the foliar application of silicon influences (positively) the response of barley plants at the physiological level to salinity stress. Moreover, the use of different doses of silicon in conditions of salinity stress differentially affects the level of DNA methylation, relative chlorophyll content as well as gas exchange or chlorophyll fluorescence parameters.

\section{Results}

\subsection{Effect of Salinity and Foliar Application of Si on the Relative Chlorophyll Content of Barley} Leaves (CCI)

The chlorophyll content in the leaves increased with time, regardless of the experimental variant used. For plants grown under saline conditions (without foliar application of $\mathrm{Si}$ ) the differences in the relative content of chlorophyll between the control plants and the $\mathrm{NaCl}$ variant plants increased with time (Figure 1). In the last measurement period (Date IV), 56.8\% less chlorophyll was present in the leaves of these plants in comparison with the control plants. The foliar application of silicon in each concentration increased the chlorophyll content in the leaves at each measurement period, compared to the $\mathrm{NaCl}$ variant plants, which was statistically confirmed (Figure 1). The use of silicon in a dose of $0.1 \%$ and $0.2 \%$ caused a similar amount of chlorophyll to be accumulated in the plant leaves as in the control plants, despite their being grown in saline conditions. This relationship proves the positive effect of $\mathrm{Si}$ on the accumulation of chlorophyll in barley leaves grown under stressful conditions.

\subsection{Influence of Salinity and Foliar Application of Si on Gas Exchange Parameters}

The $C_{i}$ parameter depended on the applied experience factors (Figure 2A). The lowest values of $C_{i}$ in each of the measurement periods were noted in plants with $\mathrm{NaCl}$ without foliar application of $\mathrm{Si}$. After the application of $\mathrm{Si}$, in the first measurement period (two days after the application of the first dose), the plants with $0.1 \%$ and $0.2 \%$ foliar application of $\mathrm{Si}$ had a value of $\mathrm{C}_{\mathrm{i}} 4.5 \%$ and $3.8 \%$ higher, respectively, in comparison with the control plants. The application of silicon at a level of $0.05 \% \mathrm{Si}$ caused a statistically significant increase in the measured value of the $C_{i}$ parameter compared to the plants grown under salt stress in the second, third and fourth measurement period. Two days after the application of $\mathrm{Si}$ (Date I, III), higher $\mathrm{C}_{\mathrm{i}}$ values were noted at the same $\mathrm{Si}$ concentration when compared to the results obtained on Day 7 (Date II and IV). At the date of the third measurement (two days after the second silicon application), an increased $C_{i}$ was noted in each variant treated with $\mathrm{Si}$, to reach a level comparable with the control plants. 


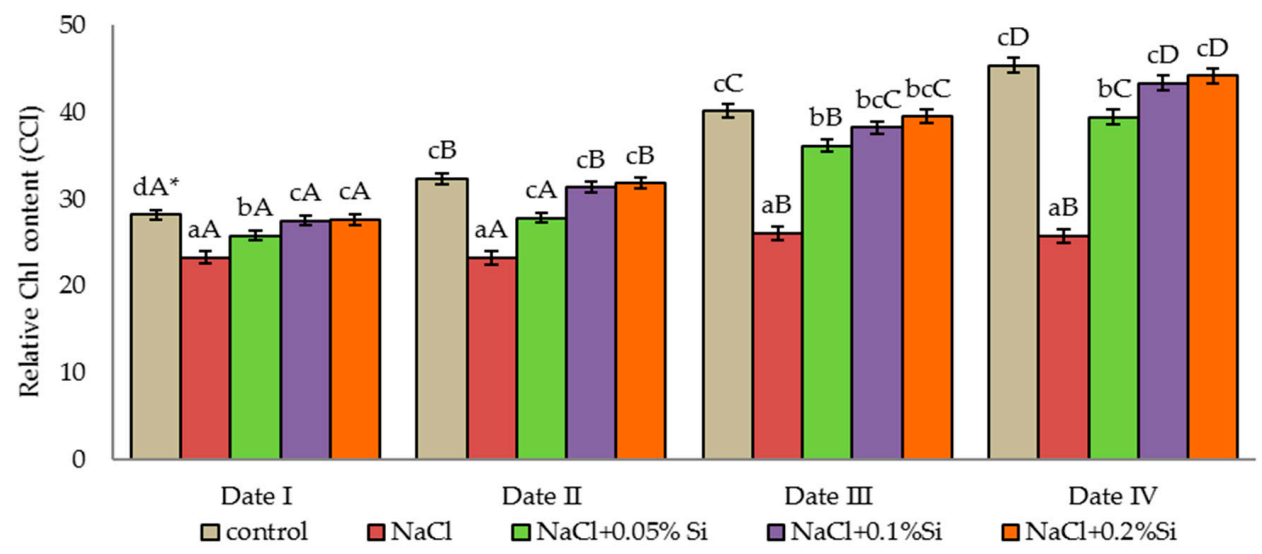

Figure 1. The effect of $\mathrm{NaCl}$, different $\mathrm{Si}$ concentration and measurement date on the chlorophyll content in the leaves (CCI); (Date I and Date II, 2 and 7 days after first Si application; Date III and Date IV, 2 and 7 days after second Si application) statistical data are expressed as mean \pm SD values. * Capital letters indicate significant differences between the means in the measurement dates for particular Si concentrations, and lowercase letters indicate significant differences between the means at subsequent measurement dates $(p=0.05)$.
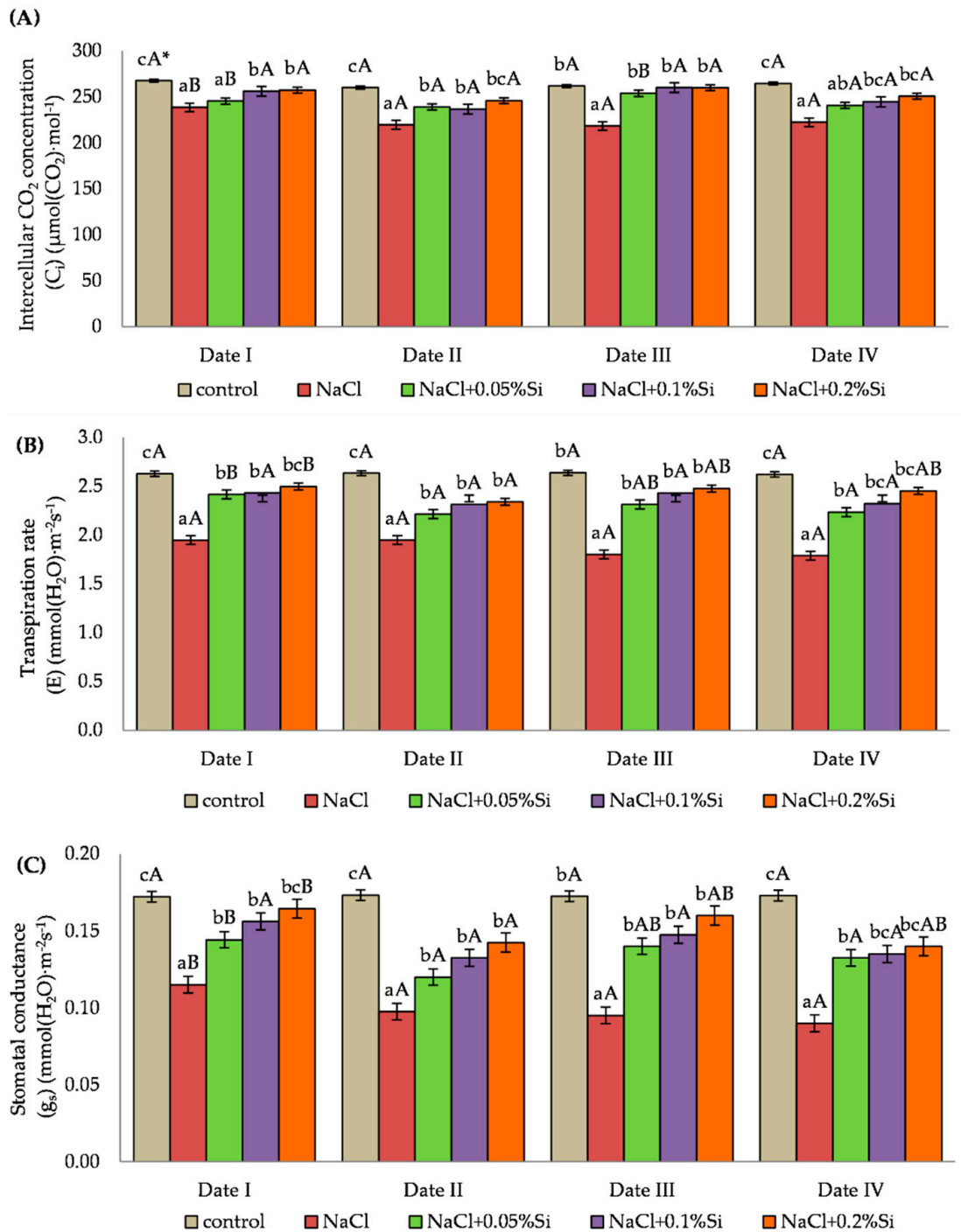

Figure 2. Cont. 


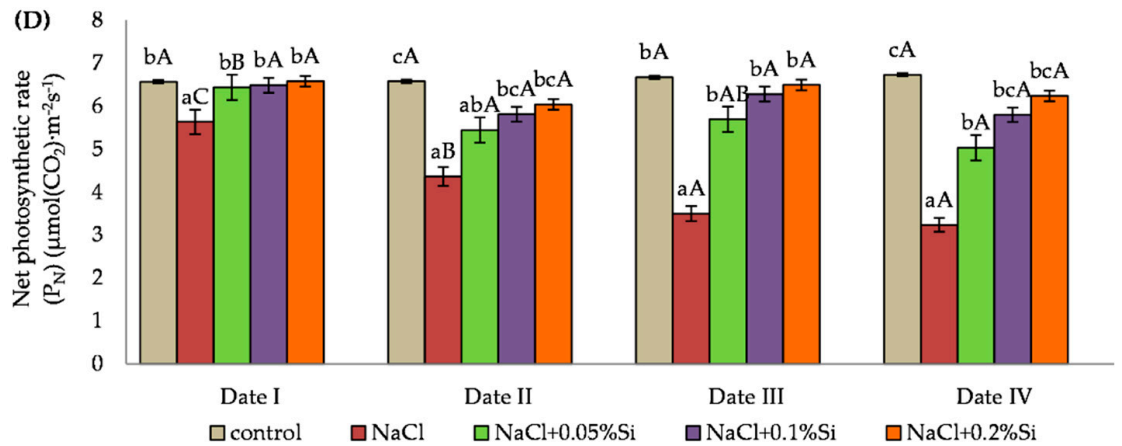

Figure 2. The effect of $\mathrm{NaCl}$, different $\mathrm{Si}$ concentration and measurement date on gas exchange parameters: intercellular $\mathrm{CO}_{2}$ concentration $\left(\mathrm{C}_{\mathrm{i}}\right)(\mathrm{A})$, transpiration rate $(\mathrm{E})(\mathbf{B})$, stomatal conductance $\left(g_{s}\right)(C)$ and net photosynthetic rate $\left(P_{N}\right)(D)$ in barley plants (Date I and Date II, 2 and 7 days after first Si application; Date III and Date IV, 2 and 7 days after second Si application). Statistical data are expressed as mean $\pm S D$ values. ${ }^{*}$ Capital letters indicate significant differences between the means in the measurement dates for particular Si concentrations, and lowercase letters indicate significant differences between the means at subsequent measurement dates $(p=0.05)$.

For the barley plants grown under salt stress (without $\mathrm{Si}$ ) the value of the $\mathrm{E}$ transpiration coefficient was reduced by an average of $28.8 \%$ when compared to the control plants. The use of silicon, regardless of the concentration, caused an increase of $\mathrm{E}$ in comparison with the salt stressed plants in each measurement period. During analysis of the influence of the measurement period on the impact of silicon under saline conditions, higher values were recorded with the concentration of $0.05 \% \mathrm{Si}$ over the first and third measurement periods (two days after Si application) than over the second and fourth periods (seven days after $\mathrm{Si}$ application). The greatest impact of $\mathrm{Si}$ on the growth of $\mathrm{E}$ in saline conditions was demonstrated at the higher concentrations of $0.1 \%$ and $0.2 \%$ (Figure $2 \mathrm{~B}$ ).

Stomatal conductance $\left(\mathrm{g}_{\mathrm{s}}\right)$ was determined by the experimental factors applied. A decrease by on average $42.5 \%$ in the value of the $g_{s}$ parameter in plants grown under salt stress (only $\mathrm{NaCl}$ ) was noted when compared to the control plants. The use of Si caused an increase in the measured values of the parameter, and the highest values were seen with concentrations of $\mathrm{Si}$ of $0.1 \%$ and $0.2 \%$ in each measurement period when compared to the salt stressed plants (only $\mathrm{NaCl}$ ). Significant differences in $\mathrm{g}_{\mathrm{s}}$ values were observed between the measurement periods. The highest values were observed on the second day after $\mathrm{Si}$ application (Date I and Date III) (Figure 2C).

Salt stress had a negative effect on the $\mathrm{P}_{\mathrm{N}}$ index, causing it to decrease. A decrease was observed in the plants with $\mathrm{NaCl}$ and the $\mathrm{NaCl}+\mathrm{Si}$ variant in comparison with the control plants (Figure 2D). The foliar application of Si caused an increase in $P_{N}$ in each measurement period. The highest values were obtained two days after the foliar application of Si (Date I and Date III). In the first measurement period, the use of silicon in plants grown under salt stress caused an increase of the $P_{N}$ index to a value similar to the value of the control plants. In the following periods the $\mathrm{P}_{\mathrm{N}}$ value decreased when compared to the control plants, but it was still higher when compared to the plants grown under $\mathrm{NaCl}$ stress. The duration of the salt stress has an impact on the decrease of the $P_{N}$ value in plants where Si was not applied exogenously. In the fourth measurement period, the $\mathrm{P}_{\mathrm{N}}$ value was $42.5 \%$ lower when compared to the result obtained in the first period. The use of $\mathrm{Si}$ in the second measurement period at concentrations of $0.1 \%$ and $0.2 \%$ increased the $P_{N}$ index by $33.0 \%$ and $38.3 \%$, respectively, in comparison with $\mathrm{NaCl}$ variant plants. The $\mathrm{P}_{\mathrm{N}}$ index value with the $0.05 \% \mathrm{Si}$ concentration on the second day after application (Date I and Date III) was higher than on the seventh day (Date II and Date IV) by an average of $13.7 \%$, which was statistically confirmed.

The values of $g_{s}$ and $P_{N}$ parameters shortly after $\mathrm{Si}$ application (two days after spraying) for each Si concentration were similar. Seven days after the application of $\mathrm{Si}$, the significantly highest values were recorded at the concentrations of $0.1 \%$ and $0.2 \% \mathrm{Si}$. The 
use of $\mathrm{Si}$ in higher concentrations resulted in a longer positive effect on the values of gas exchange parameters compared to the concentration of $0.05 \% \mathrm{Si}$ (Figure $2 \mathrm{C}, \mathrm{D}$ ).

\subsection{Influence of Experimental Factors on the Chlorophyll Fluorescence Parameters}

In the first measurement period, salinity and foliar application of silicon had no significant effect on the $\mathrm{F}_{\mathrm{v}} / \mathrm{F}_{\mathrm{m}}$ value. Lower values of the parameter examined were observed in plants which had an application of salt alone when compared to plants to which silicon had been applied, but these differences were not statistically confirmed. In the next measurement periods of $\mathrm{F}_{\mathrm{v}} / \mathrm{F}_{\mathrm{m}}$ (Date II, III and IV), the use of silicon at a concentration of $0.1 \%$ and $0.2 \%$ Si caused a significant increase in $\mathrm{F}_{\mathrm{v}} / \mathrm{F}_{\mathrm{m}}$ in comparison with plants with $\mathrm{NaCl}$ and the $\mathrm{NaCl}+0.05 \%$ Si variant (Figure $3 \mathrm{~A}$ ).
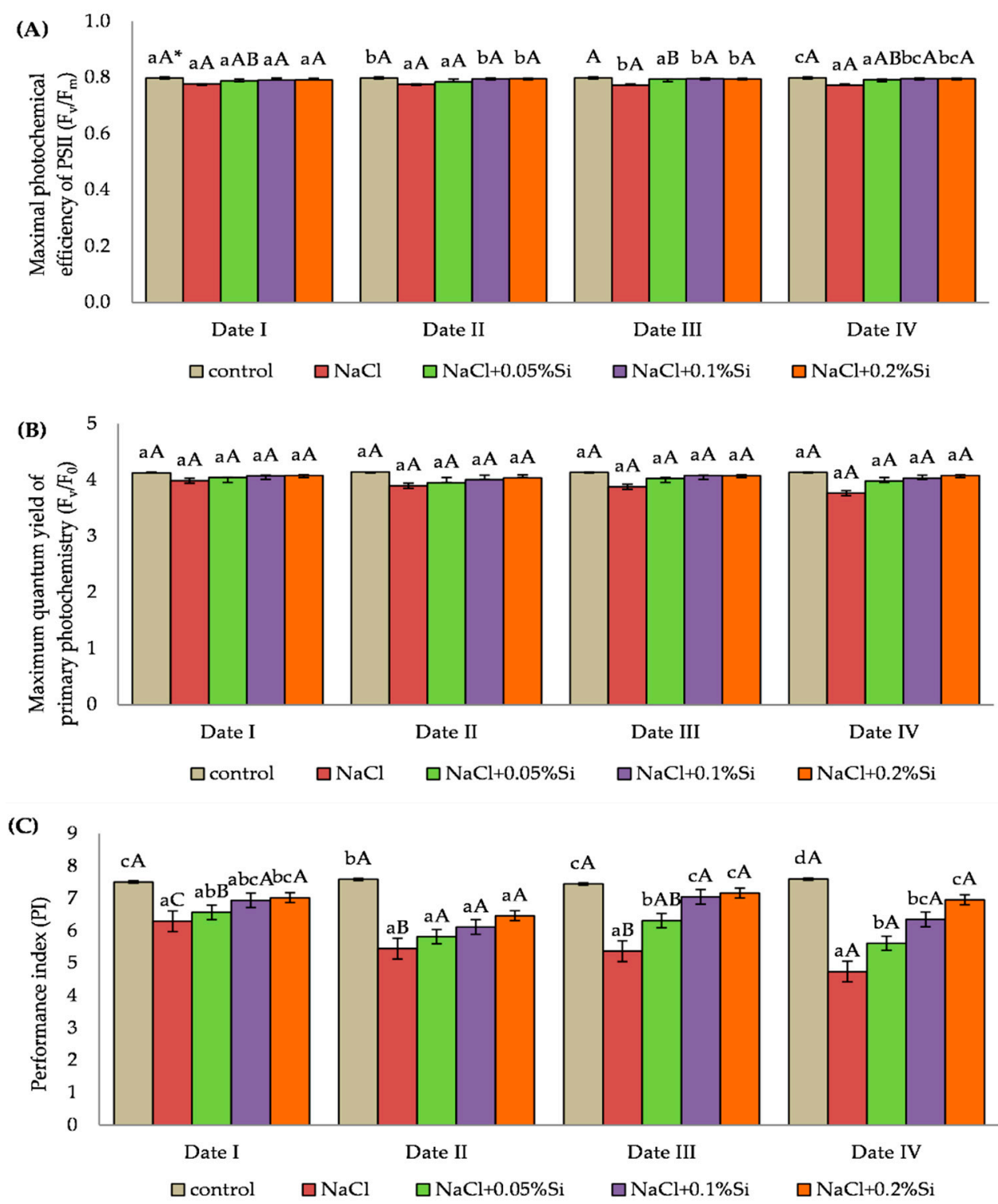

Figure 3. Cont. 


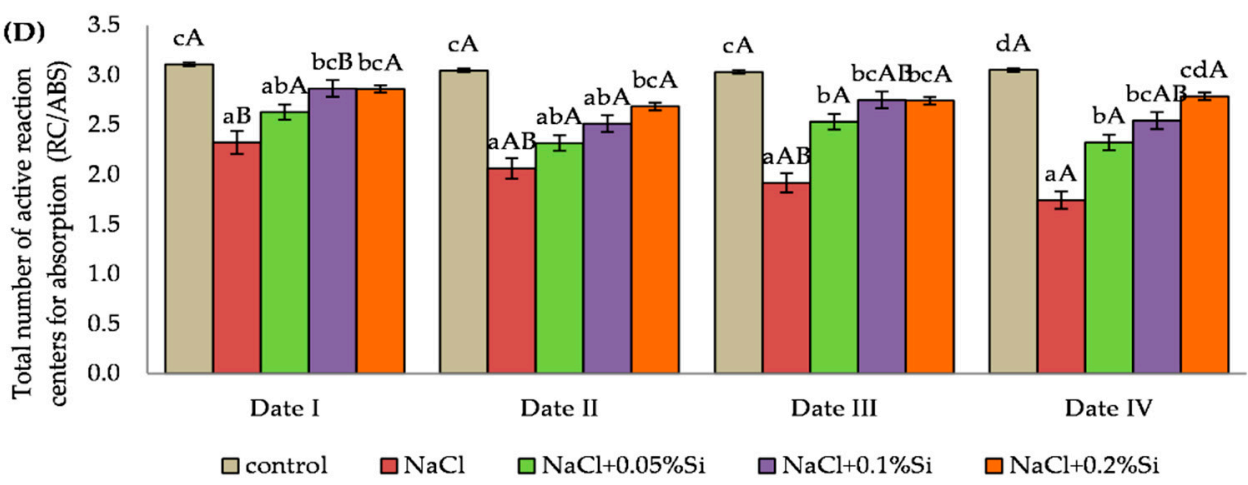

Figure 3. The effect of $\mathrm{NaCl}$, different $\mathrm{Si}$ concentration and measurement date on chlorophyll fluorescence parameters: maximal quantum yield of PSII photochemistry $\left(F_{v} / F_{m}\right)(A)$, maximum primary photochemistry yield $\left(\mathrm{F}_{\mathrm{V}} / \mathrm{F}_{0}\right)(\mathrm{B})$, PS II performance index (PI) (C) and total number of active reaction centers for absorption (RC/ABS) (D) in barley plants (Date I and Date II, 2 and 7 days after first Si application; Date III and Date IV, 2 and 7 days after second Si application). Statistical data are expressed as mean \pm SD values. ${ }^{*}$ Capital letters indicate significant differences between the means in the measurement dates for particular Si concentrations, and lowercase letters indicate significant differences between the means at subsequent measurement dates $(p=0.05)$.

The analysis of variance did not show any significant influence of salinity and foliar application of silicon on the $\mathrm{F}_{\mathrm{v}} / \mathrm{F}_{0}$ value. The plants grown under salt stress (without $\mathrm{Si}$ ) had lower values of the study parameter when compared to the control plants, but they were not statistically significant. Higher $\mathrm{F}_{\mathrm{v}} / \mathrm{F}_{0}$ values were also observed after application of $\mathrm{Si}$ over each measurement period compared to the $\mathrm{NaCl}$ variant, but this increase was not significant. The highest values, when compared to the control plants, were observed for the plants with $\mathrm{NaCl}+0.2 \% \mathrm{Si}$ variant (Figure 3B).

The PI value depended on both salinity and application of Si (Figure 3C). Plants with $\mathrm{NaCl}$ and without foliar application of Si showed a decrease in PI over time. Over the fourth measurement period, the value of the parameter measured in plants with the $\mathrm{NaCl}$ variant was $24.7 \%$ lower when compared with the first measurement period. Exogenous use of $\mathrm{Si}$ caused an increase in the measured value of the parameter. The highest values in salt stressed plants were recorded at the concentrations of $0.1 \%$ and $0.2 \% \mathrm{Si}$. In plants where silicon was applied, a higher PI value was observed on the second day after application of $\mathrm{Si}$ (Date I and III) when compared to the results obtained on the seventh day after foliar application of Si (Date II and IV) (Figure 3C).

Salinity had a negative effect on the $\mathrm{RC} / \mathrm{ABS}$ value. Plants with $\mathrm{NaCl}$ had statistically significant lower values of the measured parameter in comparison with the control plants. Application of $\mathrm{Si}$ at each concentration caused an increase in RC/ABS. The highest values in plants grown under salinity stress were observed at the $\mathrm{Si}$ concentration of $0.1 \%$ and $0.2 \%$ (Figure 3D). The analysis of the impact of the measurement period showed a decrease of RC/ABS along with the duration of the stress in plants with the $\mathrm{NaCl}$ variant. In the fourth measurement period, the RC/ABS value was $25.0 \%$ lower compared to the first period, which was confirmed by the analysis of variance. The highest RC/ABS values in plants grown under salinity stress and silicon application were noted on the second day after application (Date I and III) (Figure 3D).

\subsection{Effect of Salinity and Foliar Application of Silicon on the Level of DNA Methylation}

In the presented study, thirteen combinations of selective EcoRI and MspI/HpaII primers were used and the numbers of hemimethylated and fully methylated cytosine at $5^{\prime}$ CCGG ' 3 restriction sites were calculated in barley plants treated with $\mathrm{NaCl}$ or in combination with $\mathrm{NaCl}+\mathrm{Si}$. DNA methylation profiles with polymorphic fragments occurrence were obtained for an individual analyzed groups of barley plants (Figure 4). 


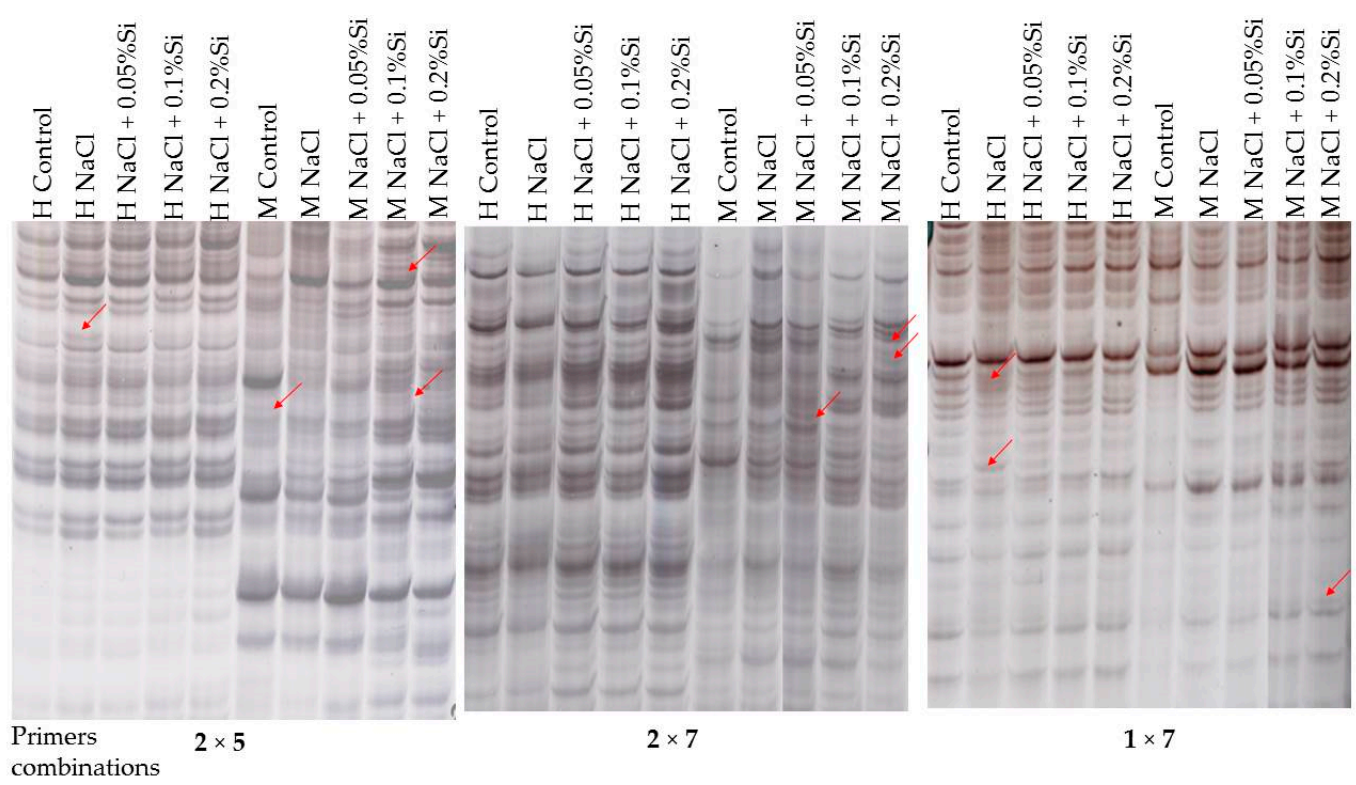

Figure 4. Comparison of representative MSAP gels. $\mathrm{H}$ and $\mathrm{M}$ refer to digestion with EcoRI $+H p a \mathrm{II}$ and EcoRI $+M s p I$, respectively. Arrows indicate polymorphic bands.

The highest number of DNA fragments were detected in the case of barley plants treated with $\mathrm{NaCl}$ in combination with $0.1 \%$ and $0.2 \% \mathrm{Si}$, whereas the smallest amount of selective amplification DNA products was detected in the case of control barley plants (Table 1).

Table 1. Summary of DNA methylation level.

\begin{tabular}{cccccc}
\hline Analyzed Values & Control & $\mathbf{N a C l}$ & $\begin{array}{c}\mathbf{N a C l}+ \\
\mathbf{0 . 0 5} \% \mathbf{S i}\end{array}$ & $\begin{array}{c}\mathbf{N a C l}+ \\
\mathbf{0 . 1} \% \mathbf{S i}\end{array}$ & $\begin{array}{c}\mathbf{N a C l}+ \\
\mathbf{0 . 2} \% \mathbf{S i}\end{array}$ \\
\hline Total bands number & 858 & 878 & 895 & 952 & 938 \\
\hline $\begin{array}{c}\text { Number of symmetric } \\
\text { methylation bands }\end{array}$ & 159 & 114 & 137 & 80 & 85 \\
\hline Symmetric methylation (\%) & $19 \%$ & $13 \%$ & $15 \%$ & $8 \%$ & $9 \%$ \\
\hline Number of hemimethylation bands & 89 & 90 & 78 & 78 & 91 \\
\hline Hemimethylation bands (\%) & $10 \%$ & $10 \%$ & $9 \%$ & $8 \%$ & $10 \%$ \\
\hline$\%$ total methylation & $29 \%$ & $23 \%$ & $24 \%$ & $17 \%$ & $19 \%$ \\
\hline
\end{tabular}

However, the number of methylation events was the lowest (17\%) in the case of barley plants treated with $\mathrm{NaCl}$ and a moderate dose of $\mathrm{Si}(0.1 \%)$ (Table 1). Barley plants treated with $\mathrm{NaCl}$ and the highest dose of $\mathrm{Si}(0.2 \%)$ characterized comparably a low level of methylation (19\%) (Table 1). In both groups of barley plants, we obtained an almost similar number of PCR products that represented hemi- as well as symmetric methylation of the $5^{\prime}$ CCGG 3' sequence.

Simultaneously, the highest percentage of methylation events was observed in the case of a control group of barley plants, whereas plants treated with $\mathrm{NaCl}$ or with a combination with the lowest dose of $\mathrm{Si}(0.05 \%)$ demonstrated a moderate level of methylation events (Table 1). The mentioned group of barley plants characterized a clear advantage of the symmetric methylation of the $5^{\prime} \mathrm{CCGG} 3^{\prime}$ sequence in comparison to hemimethylation. However, in the case of control group plants, the difference was the most distinguished. 


\section{Discussion}

Abiotic stresses cause a number of changes in the physiological and biochemical processes as well as on the epigenetic level in plants. Salinity has a negative effect on photosynthesis, which is the most basic and complex physiological process of green plants. Any damage at any stage of the photosynthetic process due to stress can reduce the overall photosynthetic efficiency of plants [22]. The plants in our study were treated with $\mathrm{NaCl}$ at a level of $200 \mathrm{mM}$. Excessive amounts of $\mathrm{Na}^{+}$and $\mathrm{Cl}^{-}$ions in the soil solution induce ionic toxicity by disrupting the structure of enzymes, damaging cell organelles and disrupting cellular metabolism [88-90]. In addition, they lead to the accumulation of hazardous substances in plant cells, especially ROS, such as singlet oxygen $\left(\mathrm{O}_{2}\right)$, superoxide radicals $\left(\mathrm{O}^{2-}\right)$ and hydrogen peroxide $\left(\mathrm{H}_{2} \mathrm{O}_{2}\right)$, which cause oxidative stress and damage proteins, lipids and nucleic acids [91,92]. Energy in the form of ATP triggers biosynthetic reactions in plant cells, which are mainly produced by chloroplasts and mitochondria. When plants are exposed to salinity stress, energy requirements can increase significantly to trigger several energy-intensive adaptive mechanisms ensuring ionic homeostasis, ROS defense and osmotic regulation [93]. Excessive dissipation of photosynthetic energy may have an impact on defensive photo-damage, photoinhibition and photo-oxidative salinity tolerance [94].

Plants are characterized by various levels of salt tolerance [23]. Barley is classified as a species relatively resistant to salinity, but high concentrations of $\mathrm{NaCl}$ negatively affect its growth and yield [10]. Chlorophyll is one of the most important features indicating the health condition of plants [95]. The results of the research indicate a negative effect of a high concentration of $\mathrm{NaCl}$ in the soil on the relative amount of chlorophyll in leaves and the parameters of plant gas exchange and chlorophyll fluorescence. The chlorophyll content in our study increased over time, but the plants under salinity stress had a lower chlorophyll content when compared to the control plants. A significant decrease in the chlorophyll content in the leaves of plants grown under salinity stress was also noted by other researchers [10,96-99]. The reduction of photosynthetic pigments may be caused by the breakdown of the thylakoid membranes by the formation of proteolytic enzymes responsible for the degradation of chlorophyll, as well as a result of damage of the photosynthetic apparatus $[24,100]$. In our research, foliar application of silicon in any concentration increased the chlorophyll content in leaves of barley plants grown under salt stress. Higher values were observed after the use of silicon at concentrations of $0.1 \%$ and $0.2 \% \mathrm{Si}$ than of $0.05 \%$. Similarly, in the studies by Kalteh et al. [101] and studies by Chung et al. [102], the chlorophyll content significantly decreased in response to $\mathrm{NaCl}$ and $\mathrm{NaCl}+\mathrm{Si}$ treatment, and the decrease in the amount of chlorophyll was only greater in plants exposed to $\mathrm{NaCl}$ in comparison to control plants. An increase in the chlorophyll content in plants grown under salt stress coupled with an increase in the foliar dose of $\mathrm{Si}$ was also noted by Hellal et al. [84] and Abdelaal et al. [57].

In the plants treated with $\mathrm{NaCl}$, there was a significant decrease in the gas exchange parameters $\mathrm{P}_{\mathrm{N}}, \mathrm{E}, \mathrm{g}_{\mathrm{s}}$ and $\mathrm{C} 1$. Similarly, in barley grown under saline conditions, a reduction in stomatal conductance $\left(\mathrm{g}_{\mathrm{s}}\right)$ and rate of photosynthesis $\left(\mathrm{P}_{\mathrm{N}}\right)$ was observed in the studies by Zeehsan et al. [99]. Inhibition of plant assimilation under the influence of salt stress may be caused by a limited supply of $\mathrm{CO}_{2}$ due to the partial closure of the stomata and an impaired biochemical binding process for $\mathrm{CO}_{2}$ [103]. Plants respond to salt stress by reducing stomatal conductance to avoid excessive water loss [104]. This situation causes the reduction of the photosynthetic binding of $\mathrm{CO}_{2}$, a change in the cellular metabolism and an increase in the production of ROS in chloroplasts. ROS can damage the photosynthetic apparatus, especially PSII, causing photoinhibition due to imbalance in the photosynthetic redox signaling pathways and inhibition of PSII repair [105-108]. Our studies show that the decrease of $C_{i}$ results in a slowing down of the Calvin cycle reaction and the induction of photorespiration. This phenomenon leads to a depletion of oxidized $\mathrm{NADP}^{+}$which acts as a final electron acceptor in PSI and alternatively increases $\mathrm{O}_{2}$ electron leakage to form $\mathrm{O}^{2-}$ and finally causes the production of more $\mathrm{H}_{2} \mathrm{O}_{2}$ in the peroxisome $[15,109]$. Lower $\mathrm{g}_{\mathrm{s}}$ 
and reduced chlorophyll content may contribute to a greater inhibition of the rate of net photosynthesis $\left(\mathrm{P}_{\mathrm{N}}\right)[101,110]$. The reduction of $\mathrm{g}_{\mathrm{s}}, \mathrm{P}_{\mathrm{N}}$ and $\mathrm{E}$ under the influence of salinity was also noted in studies by other researchers $[99,111,112]$, and salt tolerance depended on the manipulation of the accumulation of $\mathrm{E}, \mathrm{g}_{\mathrm{s}}$ and $\mathrm{P}_{\mathrm{N}}$, along with increased production of antioxidant enzymes (SOD and POX) at the cellular level. The addition of Si increased the values of the gas exchange parameters that were measured. Similarly, in the studies by Yeo et al. [113], Si induced an increase of $g_{s}$ and $P_{N}$ due to the improved ultrastructural organization of chloroplasts. $\mathrm{E}, \mathrm{g}_{\mathrm{s}}$ and $\mathrm{P}_{\mathrm{N}}$ also increased under salt stress thanks to the use of silicon in the study by Chung et al. [102] and Li et al. [114]. The protective role of Si in the photosynthetic apparatus, as well as increased photosynthetic activity, can partially be attributed to the greater ability of plants to take up $\mathrm{K}^{+}$and the enhanced antioxidant defense [115]. The increase of gas exchange parameters caused by the foliar application of Si was also noted by De Oliveira et al. [78] in a study conducted on sorghum plants. Rios et al. [116] proposed a model which explained that Si improves the functioning of the stoma and the hydraulic conductivity of the roots by adjustment of aquaporins.

The measurement of chlorophyll fluorescence is considered to be an accurate method that permits the detection of changes in the general bioenergetic conditions of photosynthetic organisms under abiotic stress conditions [117-119]. In our studies, the parameters of chlorophyll fluorescence $\mathrm{F}_{\mathrm{v}} / \mathrm{F}_{\mathrm{m}}, \mathrm{F}_{\mathrm{v}} / \mathrm{F}_{0}$ and $\mathrm{RC} / \mathrm{ABS}$ and PI decreased in plants grown under saline conditions, which should be understood as the negative influence of salt on these parameters. The authors of the publications $[37,38]$ indicate that the analysis of chlorophyll fluorescence is useful and accurate as an indicator of plant stress, but in our studies, for the $F_{v} / F_{m}$ and $F_{v} / F_{0}$ parameters no statistically significant differences were found between the results obtained in the control plants and plants exposed to salinity stress. The negative effect of the salt was limited by the foliar application of Si. According to studies [120-122], Si supplied in the form of hydrated rock dust easily and quickly penetrates through the intercellular spaces and stoma of plants, entering into biochemical reactions in cells. When compared to the seventh day, higher values of the gas exchange parameters and chlorophyll fluorescence were observed on the second day after the exogenous application of Si. The main cause of this phenomenon may be the short effect of foliar application of Si. Therefore, the next spray of Si can be treated as an action supporting the positive effect of this element on the plant. According to Laane [81], for most crops, it is optimal to spray the plants 3-4 times during the growing season. The $\mathrm{F}_{\mathrm{v}} / \mathrm{F}_{\mathrm{m}}$ ratio reflects the photochemical performance of PSII [37]. NaCl stress may disturb the biochemistry of photosynthesis, reducing the efficiency of PSI and PSII due to the disturbance of the integrity of chloroplasts [123], which was demonstrated in our own research, in which a decrease of chlorophyll content was observed in plants grown under saline conditions. The decrease of photochemical efficiency of PSII and $F_{v} / F_{m}$ in barley grown under stress was also confirmed by Zeng et al. [96] and Zeehsan et al. [99]. At the same time, the reduction of the $\mathrm{RC} / \mathrm{ABS}$ ratio as a result of salinity stress in plants was observed by Xia et al. [124] and this phenomenon was also visible in the experiment carried out. The results of our own studies and the literature indicate that increased salinity leads to many changes in energy processes, causing inactivation of reaction centers and inhibition of electron transport, while the foliar application of Si reduces the negative effects of salt in the soil environment.

MSAP analysis confirmed the existence of different levels of DNA methylation among barley plants treated with $\mathrm{NaCl}$ or in combination $\mathrm{NaCl}+\mathrm{Si}$ (Table 1). Barley plants in the control condition (without being $\mathrm{NaCl}$ treated) characterized the highest level of DNA methylation. In the case of barley plants treated with $\mathrm{NaCl}$, the total level of methylation decreased. The obtained data indicated the lowest percentage of methylation in the case of barley plants treated with $\mathrm{NaCl}$ in combination with moderate $(0.1 \%)$ and highest $(0.2 \%)$ dose of Si (Table 1). Decreased methylation level in stress conditions was also proven in tobacco [125], rice [45] and wheat [48]. Moreover, Ferreira et al. [45] indicated that a salt-stress tolerance rice variety characterized a lower level of methylation than a salt stress-sensitive variety. Methylated DNA is well known to inhibit gene expression, while a 
reduction in the level of methylation leads to an increase of gene expression [126]. Obtained results indicated that in a salt stress condition linked with added $\mathrm{NaCl}$, using more than $0.1 \%$ of $\mathrm{Si}$ activated more gene expression to cope with stress conditions than without Si or with the smallest dose $(0.05 \%)$. The decrease of methylation event reflects the properties analyzed on a physiological level (chlorophyll content, gas exchanges, and fluorescence parameters). All of the analyzing features indicated the lowest value in the case of salt stress $(\mathrm{NaCl}$ treated). A combined application $\mathrm{NaCl}$ with $\mathrm{Si}(0.1 \%$ as well as $0.2 \%)$ led to a decrease of methylation (Table 1) and activation of gene expression which probably could result in the increase of chlorophyll level, gas exchange efficiency and chlorophyll fluorescence parameters. However, to confirm this assumption, further analyses, including the investigation expression of specific genes, are required. According to the obtained results, a connection between the ability of DNA methylation adjustment levels and salt stress tolerance can be inferred. Abiotic stresses may cause heritable alterations in cytosine methylation by forming novel epialleles [47,127]. It has been found that plants not only adopt changes for the prevailing stress scenario but also remember this information for the next generation to efficiently cope with such environmental conditions [127]. The memory of a specific environmental stress ability of plants is called 'plant memory' or 'epigenetic memory'. This memory provides a smart basis for a strong and quick response to such future stress challenges [128].

The results of the work indicated differences in the reaction of barley plants on the physiological and epigenetic level in reaction on salt stress. We proved that barley plants which were treated in combination with $\mathrm{NaCl}$ and $\mathrm{Si}(0.1 \%$ or $0.2 \%)$ indicated higher physiological parameters (chlorophyll content and fluorescence or gas exchange) in comparison to barley plants growing in salt stress condition without adding Si. These results of physiological parameters may be an effect of methylation level reduction. Therefore, it can be inferred that the methylation pattern of barley plants treated with $\mathrm{Si}$ is at least partly remembered and inherited. This heritable memory, called 'plant stress memory', enables plants to respond against stresses in a better and efficient way, not only for the current plant in prevailing situations but also for future generations. The epigenetic memory of barley plans treated with $\mathrm{Si}(0.1 \%$ as well as $0.2 \%)$ will in the future be responsible for appropriate plant reactions to changes to environmental conditions caused, for example, by salinity.

\section{Materials and Methods}

\subsection{Plant Material and Growing Conditions}

A controlled pot experiment was carried out at the University of Rzeszow (Poland). Seeds of the RGT Planet variety of spring barley were sown in $10 \mathrm{~cm}$ diameter pots in which was placed $1.5 \mathrm{~kg}$ of soil with a grain size of clay sand and a slightly acidic $\mathrm{pH}$ ( $\mathrm{pH}$ : $\mathrm{KCl}$ 6.35; $\mathrm{H}_{2} \mathrm{O}$ 6.52). The total content of compounds in the soil: tetraphosphorus decaoxide $\left(\mathrm{P}_{2} \mathrm{O}_{5}\right) 17.4 \mathrm{mg} \cdot 100 \mathrm{~g}^{-1}$, potassium oxide $\left(\mathrm{K}_{2} \mathrm{O}\right) 17.0 \mathrm{mg} \cdot 100 \mathrm{~g}^{-1}$, magnesium $(\mathrm{Mg}) 8.87 \mathrm{mg} \cdot 100 \mathrm{~g}^{-1}$, calcium (Ca) $9.46 \mathrm{mg} \cdot 100 \mathrm{~g}^{-1}$. The experiments were carried out in a growth chamber (Model GC-300/1000, JEIO Tech Co., Ltd., Seoul, Korea) at a temperature of $22 \pm 2{ }^{\circ} \mathrm{C}, 60 \pm 3 \% \mathrm{RH}$, and a photoperiod of 16:8 h light:darkness. The experiment was conducted in a randomized block design with four replicates. The positions of the pots in the experiment were randomly changed every week.

First, sodium chloride $(\mathrm{NaCl})$ was used as the experimental factor. In the sprout stage of plant growth (the stage of the first pair of leaves), an aqueous solution of $\mathrm{NaCl}$ with a concentration of $200 \mathrm{mM}$ in a volume of $50 \mathrm{~cm}^{3}$ was applied once to the soil in each pot. The silicon was used twice-after 7 and 14 days from the application of the $\mathrm{NaCl}$ solution. Foliar application of $\mathrm{Si}\left(200 \mathrm{~g}^{-1} \mathrm{SiO}_{2}\right)$ was given in three concentrations of 0.05 , 0.1 and $0.2 \%$. Spraying was performed with a laboratory hand sprayer with flow control of a dosing volume of $1.2 \mathrm{~mL} \pm 0.1$ during one press (outlet diameter $0.6 \mathrm{~mm}$ ). This was applied via a uniform spraying procedure. Plants were sprayed until they were dripping. Deionized water was applied at the same time to the control pots. Plants in pots without $\mathrm{NaCl}(0 \mathrm{mM}$ without addition of $\mathrm{NaCl}$ and $\mathrm{Si}$ ) were used as controls. 
Physiological measurements taking place in barley plants were made four times on the first or second fully developed leaves at two- and seven-day intervals after each application of silicon.

\subsection{Measurement of the Relative Content of Chlorophyll}

Two untouched, fully developed leaves in every pot were used to measure the relative chlorophyll content (CCI). Measurement was made using a CCM-200plus hand-held chlorophyll content meter (Opti-Sciences, Hudson, NH, USA). In total, 40 measurements were made per concentration (10 measurements repeated 4 times).

\subsection{Measurement of Chlorophyll Fluorescence}

A continuous excitation Pocket PEA chlorophyll fluorimeter (Pocket PEA, Hansatech Instruments, King's Lynn, Norfolk, UK) was used to measure chlorophyll fluorescence. This instrument is equipped with clips to darken the leaves which are attached to the leaf blade away from the leaf nerve. The following parameters were measured: maximum quantum yield of PSII photochemistry $\left(\mathrm{F}_{\mathrm{v}} / \mathrm{F}_{\mathrm{m}}\right)$, maximum quantum yield of primary photochemistry $\left(\mathrm{F}_{\mathrm{V}} / \mathrm{F}_{0}\right)$, photosynthetic efficiency index $(\mathrm{PI})$ and total number of active reaction centers for absorption (RC/ABS). The fluorescence signal was collected in actinic red light with a peak wavelength of the light source of $627 \mathrm{~nm}$ and transmitted for $1 \mathrm{~s}$ at the maximum available intensity of $3500 \mu \mathrm{mol}$ (photon) for photosynthetically active radiation (PAR) $\mathrm{m}^{-2} \cdot \mathrm{s}^{-1}$. Fluorescence measurements were performed three times in each pot on the medial leaf blade after 30 min dark adaptation.

\subsection{Measurement of Gas Exchange}

The LCpro-SD photosynthesis measurement system (ADC Bioscientific Ltd., Herts, UK) was used to measure the photosynthesis of the leaves. The LCpro-SD plat leaf chamber for photosynthesis has a flow accuracy of $\pm 2 \%$ of its range. During the measurement, the light intensity in the chamber was $350 \mu \mathrm{mol} \mathrm{m}{ }^{-2} \cdot \mathrm{s}^{-1}$, and the temperature was $23 \pm 2{ }^{\circ} \mathrm{C}$. Intercellular $\mathrm{CO}_{2}$ concentration $\left(\mathrm{C}_{\mathrm{i}}\right)$, transpiration rate $(\mathrm{E})$, stomatal conductance $\left(\mathrm{g}_{\mathrm{s}}\right)$ and net photosynthesis rate $\left(\mathrm{P}_{\mathrm{N}}\right)$ were measured on two fully developed leaves $(n=3)$.

\subsection{Methylation-Sensitive Amplification Polymorphism (MSAP) Assay}

The materials used in this study included fully expanded leaves of the young seedlings collected on the last day of the experiment. DNA was extracted from fresh leaves of barley plants using the method described by Doyle and Doyle [129]. The MSAP analysis was performed using the protocol described by Xiong et al. [40] and Peraza-Echeverria et al. [44] with some modifications.

Two restriction enzymes, HpaII and MspI, were used to detect cytosine methylation. Both enzymes recognize the tetranucleotide sequence $5^{\prime}$ CCGG $3^{\prime}$. The ability to cleave at the recognized sequence is affected by the methylation state of the external or internal cytosine residues. The HpaII is inactive if one or both cytosines are fully methylated (both strands methylated; symmetric methylation) but cleaves the hemimethylated sequence (only one DNA strand methylated), whereas $M s p$ I cleaves 5'CmCGG 3' but not 5'mCCGG $3^{\prime}[38,42]$. To detect MSAP, two digestion reactions were set up at the same time for each genomic DNA sample. In the first reaction, $0.5 \mu \mathrm{g}$ of the genomic DNA was digested with $10 \mathrm{U}$ of EcoRI (Thermo Scientific, Waltham, MA, USA) plus $10 \mathrm{U}$ of MspI (Thermo Scientific) and 1x Tango buffer (Thermo Scientific) in a final volume of $20 \mu \mathrm{L}$ for $6 \mathrm{~h}$ at $37^{\circ} \mathrm{C}$. The second digestion reaction was carried out as above, however, HpaII (Thermo Scientific) was used instead of MspI. Inactivation were performed at $65{ }^{\circ} \mathrm{C}$ for $20 \mathrm{~min}$.

The digestion reactions were then ligated to the adapters by adding $30 \mu \mathrm{L}$ of ligation mixture containing $1 \times$ T4 DNA ligase buffer (Invitrogen, Waltham, MA, USA), 1 U T4 DNA ligase (Invitrogen), 10 pmol EcoRI adapter (GenoMed, Warsaw, Poland) and 50 pmol MspI-HpaII adapter (GenoMed) (Table 2). The ligation reaction was incubated at $20{ }^{\circ} \mathrm{C}$ for 
overnight. The digestion and ligation reactions were stopped by incubating at $70^{\circ} \mathrm{C}$ for $10 \mathrm{~min}$.

Table 2. Sequences of adapters and primers used for MSAP analysis.

\begin{tabular}{ccc}
\hline MSAP Stage & Primers/Adapters & Sequences \\
\hline \multirow{2}{*}{ Ligation } & EcoRI-Adapter & 5'CTCGTAGACTGCGTACC 3' $^{\prime}$ 3'CATCTGACGCATGGTTAA 5 $^{\prime}$ \\
\cline { 2 - 3 } & MspI-HpaII-Adapter & $5^{\prime}$ CGACTCAGGACTCAT 3 \\
& $3^{\prime}$ TGAGTCCTGAGTAGCAG 5' \\
\hline \multirow{2}{*}{ Preamplification } & Pre-EcoRI & 5'GACTGCGTACCAATTC 3' $^{\prime}$ \\
\cline { 2 - 3 } & Pre-MspI-HpaII & 5'GATGAGTCCTGAGTCGG 3' $^{\prime}$ \\
\hline
\end{tabular}

The preamplification reaction was performer by using $2.5 \mu \mathrm{L}$ of the above ligation product with $0.5 \mu \mathrm{M}$ Pre-EcoRI primer (GenoMed) and $0.5 \mu \mathrm{M}$ Pre-MspI-HpaII primer (GenoMed) with $1 \times$ PCR buffer (Dream Taq, Thermo Scientific, Waltham, MA, USA), 1 U Taq polymerase (Dream Taq, Thermo Scientific), $200 \mu \mathrm{M}$ each of dNTP, in a final volume of $20 \mu \mathrm{L}$. The reaction involved 30 cycles of $94{ }^{\circ} \mathrm{C}$ for $30 \mathrm{~s}, 46^{\circ} \mathrm{C}$ for $1 \mathrm{~min}, 72{ }^{\circ} \mathrm{C}$ for $1 \mathrm{~min}$, with a final extension at $72{ }^{\circ} \mathrm{C}$ for $5 \mathrm{~min}$. Pre-selective PCR products were checked by electrophoresis in $2 \%$ agarose gels.

Selective amplification was conducted in volumes of $20 \mu \mathrm{L}$. For selective amplification the preamplified mixtures were diluted 10 times from their original volume with $0.1 \mathrm{x}$ TE buffer. The amplification reaction was performed by using $5 \mu \mathrm{L}$ diluted product of preamplification mixed with $0.5 \mu \mathrm{M}$ of each selective primers (EcoRI and of MspIHpaII, GenoMed) (Table 2), 1 × PCR buffer (Dream Taq, Thermo Scientific), 1 U Taq DNA polymerase (Dream Taq, Thermo Scientific) and $200 \mu \mathrm{M}$ of each dNTP. Both types of selective primers (EcoRI and MspI-HpaII) comprised two or three additional selective oligonucleotides (Table 2). The amplification reactions were performed using the touchdown cycles with the following profile: 12 cycles of $94{ }^{\circ} \mathrm{C}$ for $30 \mathrm{~s}, 65^{\circ} \mathrm{C}$ for 1 min reduced by $0.7{ }^{\circ} \mathrm{C}$ per cycle and $72{ }^{\circ} \mathrm{C}$ for $1 \mathrm{~min}$ followed by 24 cycles of $94{ }^{\circ} \mathrm{C}$ for $30 \mathrm{~s}, 56{ }^{\circ} \mathrm{C}$ for $1 \mathrm{~min}, 72{ }^{\circ} \mathrm{C}$ for $1 \mathrm{~min}$, with a final extension at $72{ }^{\circ} \mathrm{C}$ for $5 \mathrm{~min}$. All amplification reactions were conducted in a thermocycler (Biometra, GmbH, Göttingen, Germany).

A full list of selective primers used in this study are presented in Table 3.

Table 3. Sequences of primers used for selective amplification.

\begin{tabular}{|c|c|c|}
\hline No. & Primer Name & Sequences \\
\hline 0 & EcoRI-ACT & 5'GACTGCGTACCAATTCACT 3' \\
\hline 1 & EcoRI-AG & 5'GACTGCGTACCAATTCAG 3' \\
\hline 2 & EcoRI-AC & 5'GACTGCGTACCAATTCAC $3^{\prime}$ \\
\hline 3 & EcoRI-AT & 5'GACTGCGTACCAATTCAT 3' \\
\hline 4 & MspI/HpaII-ATG & 5'GATGAGTCCTGAGTCGGATG 3' \\
\hline 5 & MspI/HpaII-CTA & 5'GATGAGTCCTGAGTCGGCTA 3' \\
\hline 6 & MspI/HpaII-CTC & 5'GATGAGTCCTGAGTCGGCTC 3' \\
\hline 7 & MspI/HpaII-CAT & 5'GATGAGTCCTGAGTCGGCAT 3' \\
\hline 8 & MspI/HpaII-CT & 5'GATGAGTCCTGAGTCGGCT 3' \\
\hline 9 & MspI/HpaII-GT & 5'GATGAGTCCTGAGTCGGGT 3' \\
\hline 10 & MspI/HpaII-CA & 5'GATGAGTCCTGAGTCGGCA $3^{\prime}$ \\
\hline
\end{tabular}




\section{MSAP Electrophoresis and Visualization}

The selective PCR products were finally analyzed using $6 \%$ denaturing polyacrylamide gel electrophoresis. A mixture of equal volumes of selective PCR products and denaturing formamide dye (98\% formamide, $10 \mathrm{mM}$ EDTA $\mathrm{pH} 8,0.1 \%$ bromophenol blue and 0.1\% xylene cyanol) was denatured at $95{ }^{\circ} \mathrm{C}$ for $3 \mathrm{~min}$ and immediately cooled on ice. Gels were pre-run for $30 \mathrm{~min}$ at $60 \mathrm{~W}$ first and followed to clean the wells. A $6 \mu \mathrm{L}$ amount of denatured DNA mixture was loaded in each well and subsequently the gels were run at $60 \mathrm{~W}$ for about $2 \mathrm{~h}$. The DNA fragments in gels were stained via the silver staining method following Bassam and Gresshoff [130]. The 100 bp ladder (BioTools, Inc., Jupiter, FL, USA) was used as a molecular size marker. The reproducibility of the methylation patterns was confirmed by repeating the experiments twice.

\subsection{Methylation Analysis}

According to information presented by Xiong et al. [40] and Walder [131] a DNA methylation event was detected when bands present in the gel from the reaction EcoRI $+M s p I$ (M) were absent from the reaction EcoRI + HpaII $(\mathrm{H})$. This indicated that the internal cytosine was methylated $\left(5^{\prime} \mathrm{C}^{\mathrm{m}} \mathrm{CGG} 3^{\prime}\right)$. This is regarded as the 'symmetric or full methylation'. The contrary situation, where a band was present in $\mathrm{H}$ but absent in $\mathrm{M}$, indicated that the external cytosine of one DNA strand was methylated $\left(5^{\prime \mathrm{m} C C G G} 3^{\prime}\right)$. This is regarded as the 'hemimethylated state'. Percentage methylation was calculated followed Xiangqiana et al. [132] as below:

$$
\text { Methylation }(\%)=(\text { number of methylated bands } / \text { total number of bands }) \times 100
$$

\subsection{Statistical Analysis}

Statistical analysis was performed using TIBCO Statistica 13.3.0 (TIBCO Software Inc., Palo Alto, CA, USA). In order to detect all departures from a normal distribution at $p=0.05$, the Shapiro-Wilk test was performed. The homogeneity of variance was checked. Two-way repeated measures ANOVA was then performed (with time of assessment as a factor). In order to determine and verify the relationship, Tukey's post hoc test was performed with a significance level $p \leq 0.05$.

\section{Conclusions}

The aim of the studies was to evaluate the effect of foliar application of Si on the photosynthetic apparatus, gas exchange and methylation level of barley (Hordeum vulgare L.) grown under salt stress. On the basis of the research conducted, a positive effect of Si was demonstrated on the relative content of chlorophyll in leaves and the selected parameters of chlorophyll fluorescence and gas exchange in plants. The dose of $0.2 \%$ Si turned out to be the most beneficial for barley plants grown under salt stress. The highest content of chlorophyll CCI in the leaves was reached during its application. These plants had higher gas exchange parameters $\left(\mathrm{C}_{\mathrm{i}}, \mathrm{E}, \mathrm{g}_{\mathrm{s}}, \mathrm{P}_{\mathrm{N}}\right)$ and chlorophyll fluorescence parameters $\left(\mathrm{F}_{\mathrm{v}} / \mathrm{F}_{0}\right.$, $\mathrm{F}_{\mathrm{v}} / \mathrm{F}_{\mathrm{m}}, \mathrm{PI}$ and $\mathrm{RC} / \mathrm{ABS}$ ) when compared to the Si dose of $0.05 \%$ and $0.1 \%$. The action of silicon at the level of $0.05 \%$ Si was more effective immediately after the foliar spraying of plants. Higher values were recorded on the second day after application in comparison with the seventh day after application.

The MSAP analysis confirmed the existence of different levels of DNA methylation in barley plants grown under saline soil conditions. The highest level of DNA methylation was found in barley control plants. Salt stress, as an effect of $\mathrm{NaCl}$, caused a decrease in DNA methylation in barley plants. The lowest level of DNA methylation was observed in barley plants treated with $\mathrm{NaCl}$ in combination with a moderate $(0.1 \%)$ dose of $\mathrm{Si}$. It is a well-known fact that the decreased methylation leads to an increase in gene expression. The decrease in the methylation level of barley plants treated with the $\mathrm{NaCl}+\mathrm{Si}$ mixture reflects the observed physiological properties (chlorophyll content, gas exchange, fluorescence parameters). Epigenetic changes induced by salinity stress trigger a 'plant epigenetic stress 
memory' that enables plants treated with $\mathrm{Si}$ to respond to stress in a better and more effective manner, not only for the present plants but also for future generations.

The conducted research confirmed the hypothesis that silicon foliar spraying influences (positively) the response of barley plants at the physiological level to salinity stress. Moreover, the use of different doses of silicon in conditions of salinity stress differentially affects the level of DNA methylation, relative chlorophyll content as well as gas exchange or chlorophyll fluorescence parameters. The obtained results can be used as a basis for the development of a strategy for reducing the negative impact of abiotic stresses on agricultural productivity. Foliar application of silicon can be an effective and environmentally friendly method of reducing the impact of soil salinity on crops. The application of $\mathrm{Si}$ in saline soil conditions initiates the development of resistance to stress in barley plants and may lead to an increase in yield potential and stability in the future. In order to confirm the results obtained, further analyses should be performed for other plant species. Simultaneously, an extended molecular multivariate analysis confirming that the use of $\mathrm{Si}$ leads to a decrease of methylation together with activation expression of specified genes should be performed. The obtained test results should be verified in the field because the course of weather conditions can modify the reaction of plants to stress conditions, especially during plant vegetative growth, which is one of the most important factors determining the growth and yield of crops.

Author Contributions: Conceptualization, B.S. and R.T.-S.; methodology, B.S. and M.M.; formal analysis, B.S.; investigation, B.S., R.T.-S. and M.M.; writing-original draft preparation, B.S. and M.M.; writing-review and editing, R.T.-S. All authors have read and agreed to the published version of the manuscript.

Funding: This work was financed by the financial resources of the Ministry of Science and Higher Education for scientific activities of the Institute of Agricultural Sciences, Land Management and Environmental Protection, University of Rzeszow.

Institutional Review Board Statement: Not applicable.

Informed Consent Statement: Not applicable.

Data Availability Statement: The data presented in this study are available upon request from the corresponding author upon reasonable request.

Conflicts of Interest: The authors declare no conflict of interest.

\section{References}

1. Food and Agriculture Organization of the United Nations. Intergovernmental Technical Panel on Soils. Global Status of Soil Salinization and Sodification. In Status of the World's Soil Resources: Main Report; FAO: Rome, Italy, 2015; pp. $124-127$.

2. Machado, R.M.A.; Serralheiro, R.P. Soil salinity: Effect on vegetable crop growth. management practices to prevent and mitigate soil salinization. Horticulturae 2017, 3, 30. [CrossRef]

3. Mohanavelu, A.; Naganna, S.R.; Al-Ansari, N. Irrigation induced salinity and sodicity hazards on soil and groundwater: An overview of its causes, impacts and mitigation strategies. Agriculture 2021, 11, 983. [CrossRef]

4. Isayenkov, S.V.; Maathuis, F.J. Plant salinity stress: Many unanswered questions remain. Front. Plant Sci. 2019, 10, 80. [CrossRef]

5. Awaad, H.A.; Mansour, E.; Akrami, M.; Fath, H.E.; Javadi, A.A.; Negm, A. Availability and feasibility of water desalination as a non-conventional resource for agricultural irrigation in the mena region: A review. Sustainability 2020, 12, 7592. [CrossRef]

6. Litalien, A.; Zeeb, B. Curing the earth: A review of anthropogenic soil salinization and plant-based strategies for sustainable mitigation. Sci. Total Environ. 2020, 698, 134235. [CrossRef] [PubMed]

7. Rodziewicz, P.; Swarcewicz, B.; Chmielewska, K.; Wojakowska, A.; Stobiecki, M. Influence of abiotic stresses on plant proteome and metabolome changes. Acta Physiol. Plant 2014, 36, 1-19. [CrossRef]

8. Shrivastava, P.; Kumar, R. Soil salinity: A serious environmental issue and plant growth promoting bacteria as one of the tools for its alleviation. Saudi J. Biol. Sci. 2015, 22, 123-131. [CrossRef]

9. Tuteja, N. Mechanisms of high salinity tolerance in plants. Meth. Enzymol. 2007, 428, 419-438. [CrossRef]

10. Munns, R.; Tester, M. Mechanisms of salinity tolerance. Annu. Rev. Plant Biol. 2008, 59, 651-681. [CrossRef] [PubMed]

11. Hossain, M.S.; Dietz, K.-J. Tuning of redox regulatory mechanisms, reactive oxygen species and redox homeostasis under salinity stress. Front. Plant Sci. 2016, 7, 548. [CrossRef] [PubMed]

12. Tsugane, K.; Kobayashi, K.; Niwa, Y.; Ohba, Y.; Wada, K.; Kobayashia, H. A recessive Arabidopsis mutant that grows photoautotrophically under salt stress shows enhanced active oxygen detoxification. Plant Cell 1999, 11, 1195-1206. [CrossRef] 
13. Hernández, J.A.; Ferrer, M.A.; Jiménez, A.; Barceló, A.R.; Sevilla, F. Antioxidant systems and $\mathrm{O}_{2}{ }^{-} / \mathrm{H}_{2} \mathrm{O}_{2}$ production in the apoplast of pea leaves. Its relation with salt-induced necrotic lesions in minor veins. Plant Physiol. 2001, 127, 817-831. [CrossRef] [PubMed]

14. Chaves, M.M.; Flexas, J.; Pinheiro, C. Photosynthesis under drought and salt stress: Regulation mechanisms from whole plant to cell. Ann. Botany 2009, 103, 551-560. [CrossRef] [PubMed]

15. Abogadallah, G.M. Insights into the significance of antioxidative defense under salt stress. Plant Signal. Behav. 2010, 5, 369-374. [CrossRef] [PubMed]

16. Isayenkov, S.V. Physiological and molecular aspects of salt stress in plants. Cyt. Genet. 2012, 46, 302-318. [CrossRef]

17. You, J.; Chan, Z. ROS regulation during abiotic stress responses in crop plants. Front. Plant Sci. 2015, 6, 1092. [CrossRef]

18. Apel, K.; Hirt, H. Reactive oxygen species: Metabolism, oxidative stress, and signal transduction. Ann. Rev. Plant Biol. 2004, 55, 373-399. [CrossRef] [PubMed]

19. Tripathy, B.C.; Oelmüller, R. Reactive oxygen species generation and signaling in plants. Plant Signal. Behav. 2012, 7, 1621-1633. [CrossRef] [PubMed]

20. Sies, H.; Berndt, C.; Jones, D.P. Oxidative stress. Annu. Rev. Biochem. 2017, 86, 715-748. [CrossRef] [PubMed]

21. Takahashi, S.; Badger, M.R. Photoprotection in plants: A new light on photosystem II damage. Trends Plant Sci. 2011, 16, 53-60. [CrossRef] [PubMed]

22. Sudhir, P.; Murthy, S. Effects of salt stress on basic processes of photosynthesis. Photosynthetica 2004, 42, 481-486. [CrossRef]

23. Stepien, P.; Johnson, G.N. Contrasting responses of photosynthesis to salt stress in the glycophyte Arabidopsis and the halophyte Thellungiella: Role of the plastid terminal oxidase as an alternative electron sink. Plant Physiol. 2009, 149, 1154-1165. [CrossRef]

24. Ashraf, M.; Harris, P.J.C. Photosynthesis under stressful environments: An overview. Photosynthetica 2013, 51, 163-190. [CrossRef]

25. Ashraf, M. Relationships between growth and gas exchange characteristics in some salt-tolerant amphidiploid Brassica species in relation to their diploid parents. Environ. Exp. Bot. 2011, 45, 155-163. [CrossRef]

26. Bano, A.; Fatima, M. Salt tolerance in Zea mays (L.) following inoculation with Rhizobium and Pseudomonas. Biol. Fertil. Soils 2009, 45, 405-413. [CrossRef]

27. Parihar, P.; Singh, S.; Singh, R.; Singh, V.P.; Prasad, S.M. Effect of salinity stress on plants and its tolerance strategies: A review. Environ. Sci. Pollut. Res. 2015, 22, 4056-4075. [CrossRef]

28. Fahad, S.; Hussain, S.; Matloob, A.; Khan, F.A.; Khaliq, A.; Saud, S.; Hassan, S.; Shan, D.; Khan, F.; Huang, J.; et al. Phytohormones and plant responses to salinity stress: A review. Plant Growth Regul. 2015, 75, 391-404. [CrossRef]

29. Hussain, M.; Ahmad, S.; Hussain, S.; Lal, R.; Ul-Allah, S.; Nawaz, A. Rice in saline soils: Physiology, biochemistry, genetics and management. Adv. Agron. 2018, 148, 231-287. [CrossRef]

30. Singh, J.; Thakur, J.K. Photosynthesis and Abiotic Stress in Plants. In Biotic and Abiotic Stress Tolerance in Plants; Vats, S., Ed.; Springer: Singapore, 2018; pp. 27-46. [CrossRef]

31. Jallouli, S.; Ayadi, S.; Landi, S.; Capasso, G.; Santini, G.; Chamekh, Z.; Zouari, I.; Ben Azaiez, F.E.; Trifa, Y.; Esposito, S. Physiological and molecular osmotic stress responses in three durum wheat (Triticum turgidum ssp. durum) genotypes. Agronomy 2019, 9, 550. [CrossRef]

32. Leng, P.; Yuan, B.; Guo, Y. The role of abscisic acid in fruit ripening and responses to abiotic stress. J. Exp. Bot. 2014, 65, 4577-4588. [CrossRef]

33. Lim, C.W.; Baek, W.; Jung, J.; Kim, J.H.; Lee, S.C. Function of ABA in stomatal defense against biotic and drought stresses. Int. J. Mol. Sci. 2015, 16, 15251-15270. [CrossRef] [PubMed]

34. Bücker-Neto, L.; Paiva, A.L.S.; Machado, R.D.; Arenhart, R.A.; Margis-Pinheiro, M. Interactions between plant hormones and heavy metals responses. Genet. Mol. Biol. 2017, 40, 373-386. [CrossRef] [PubMed]

35. Khaleghi, E.; Arzani, K.; Moallemi, N.; Barzegar, M. Evaluation of chlorophyll content and chlorophyll fluorescence parameters and relationships between chlorophyll $\mathrm{a}, \mathrm{b}$ and chlorophyll content index under water stress in Olea europaea cv. Dezful. World Acad. Eng. Technol. 2012, 6, 1154-1157. [CrossRef]

36. Murchie, E.H.; Lawson, T. Chlorophyll fluorescence analysis: A guide to good practice and understanding some new applications. J. Exp. Bot. 2013, 64, 3983-3998. [CrossRef]

37. Goltsev, V.N.; Kalaji, H.M.; Paunov, M.; Bąba, W.; Horaczek, T.; Mojski, J.; Kociel, H.; Allakhverdiev, S.I. Variable chlorophyll fluorescence and its use for assessing physiological condition of plant photosynthetic apparatus. Russ. J. Plant Physiol. 2016, 63, 869-893. [CrossRef]

38. Kalaji, H.M.; Schansker, G.; Brestic, M.; Bussotti, F.; Calatayud, A.; Ferroni, L.; Goltsev, V.; Guidi, L.; Jajoo, A.; Baba, W.; et al. Frequently asked questions about chlorophyll fluorescence, the sequel. Photosynth. Res. 2017, 132, 13-66. [CrossRef]

39. Stephens, K.E.; Miaskowski, C.A.; Levine, J.D.; Pullinger, C.R.; Aouizerat, B.E. Epigenetic regulation and measurement of epigenetic changes. Biol. Res. Nurs. 2018, 15, 373-381. [CrossRef]

40. Xiong, L.Z.; Xu, C.G.; Saghai Maroof, M.A.; Zhang, Q. Patterns of cytosine methylation in an elite rice hybrid and its parental lines, detected by a methylation-sensitive amplification polymorphism technique. Mol. Gen. Genet. 1999, 261, 439-446. [CrossRef]

41. Jones, P.A.; Baylin, S.B. The epigenomics of cancer. Cell 2007, 128, 683-692. [CrossRef]

42. Ashapkin, V.V.; Kutueva, L.I.; Aleksandrushkina, N.I.; Vanyushin, B.F. Epigenetic mechanisms of plant adaptation to biotic and abiotic stresses. Int. J. Mol. Sci. 2020, 21, 7457. [CrossRef] 
43. Ganguly, D.R.; Crisp, P.A.; Eichten, S.R.; Pogson, B.J. Maintenance of pre-existing DNA methylation states through recurring excess-light stress. Plant Cell Environ. 2018, 41, 1657-1672. [CrossRef]

44. Peraza-Echeverria, S.; Herrera-Valencia, A.V.; James-Kay, A. Detection of DNA methylation changes in micropropagated banana plants using methkumarylation-sensitive amplification polymorphism (MSAP). Plant Sci. 2001, 161, 359-367. [CrossRef]

45. Ferreira, L.J.; Azevedo, V.; Maroco, J.; Oliveira, M.M.; Santos, A.P. Salt tolerant and sensitive rice varieties display differential methylome flexibility under salt stress. PLoS ONE 2015, 10, e0124060. [CrossRef] [PubMed]

46. Karan, R.; de Leon, T.; Biradar, H.; Subudhi, P.K. Salt stress induced variation in DNA methylation pattern and its influence on gene expression in contrasting rice genotypes. PLoS ONE 2012, 7, e40203. [CrossRef]

47. Wang, W.S.; Pan, Y.J.; Zhao, X.Q.; Dwivedi, D.; Zhu, L.H.; Ali, J.; Fu, B.Y.; Li, Z.K. Drought-induced site-specific DNA methylation and its association with drought tolerance in rice (Oryza sativa L.). J. Exp. Bot. 2011, 62, 1951-1960. [CrossRef] [PubMed]

48. Zhong, L.; Xu, Y.; Wang, J.B. DNA-methylation changes induced by salt stress in wheat. Afr. J. Biotechnol. 2009, 8, 6201-6207. [CrossRef]

49. Wang, B.; Zhang, M.; Fu, R.; Qian, X.; Rong, P.; Zhang, Y.; Jiang, P.; Wang, J.; Lu, X.; Wang, D.; et al. Epigenetic mechanisms of salt tolerance and heterosis in upland cotton (Gossypium hirsutum L.) revealed by methylation-sensitive amplified polymorphism analysis. Euphytica 2016, 208, 477-491. [CrossRef]

50. Chen, R.; Li, M.; Zhang, H.; Duan, L.; Sun, X.; Jiang, Q.; Zhang, H.; Hu, Z. Continuous salt stress-induced long non-coding RNAs and DNA methylation patterns in soybean roots. BMC Genom. 2019, 20, 730. [CrossRef]

51. Babaeian, M.; Tavassoli, A.; Ghanbari, A.; Esmaeilian, Y.; Fahimifard, M. Effects of foliar micronutrient application on osmotic adjustments, grain yield and yield components in sunflower (Alstar cultivar) under water stress at three stages. Afr. J. Agric. Res. 2011, 6, 1204-1208. [CrossRef]

52. Sajedi, N.A.; Ardakani, M.R.; Madani, H.; Naderi, A.; Miransari, M. The effects of selenium and other micronutrients on the antioxidant activities and yield of corn (Zea mays L.) under drought stress. Physiol. Mol. Biol. Plants 2011, 17, 215-222. [CrossRef]

53. Karim, M.R.; Zhang, Y.Q.; Zhao, R.R.; Chen, X.P.; Zhang, F.S.; Zou, C.Q. Alleviation of drought stress in winter wheat by late foliar application of zinc, boron, and manganese. J. Plant. Nutr. Soil Sci. 2012, 175, 142-151. [CrossRef]

54. Niu, J.; Liu, C.; Huang, M.; Liu, K.; Yan, D. Effects of foliar fertilization: A review of current status and future perspectives. J. Soil Sci. Plant Nutr. 2021, 21, 104-118. [CrossRef]

55. Sajedi, N.; Madani, H.; Naderi, A. Effect of microelements and selenium on superoxide dismutase enzyme, malondialdehyde activity and grain yield maize (Zea mays L.) under water deficit stress. Not. Bot. Horti Agrobot. Cluj-Napoca 2011, 39, 153-159. [CrossRef]

56. Tavanti, T.R.; de Melo, A.A.R.; Moreira, L.D.K.; Sanchez, D.E.J.; dos Santos Silva, R.; da Silva, R.M.; dos Reis, A.R. Micronutrient fertilization enhances ROS scavenging system for alleviation of abiotic stresses in plants. Plant Physiol. Biochem. 2021, 160, 386-396. [CrossRef]

57. Abdelaal, K.A.A.; Mazrou, Y.S.A.; Hafez, Y.M. Silicon foliar application mitigates salt stress in sweet pepper plants by enhancing water status, photosynthesis, antioxidant enzyme activity and fruit yield. Plants 2020, 9, 733. [CrossRef]

58. Epstein, E. The anomaly of silicon in plant biology. Proc. Natl. Acad. Sci. USA 1994, 91, 11-17. [CrossRef] [PubMed]

59. Neumann, D. Silicon in plants. Prog. Mol. Subcell. Biol. 2003, 33, 149-160. [CrossRef]

60. Luyckx, M.; Hausman, J.F.; Lutts, S.; Guerriero, G. Silicon and plants: Current knowledge and technological perspectives. Front. Plant Sci. 2017, 8, 411. [CrossRef]

61. Savvas, D.; Ntatsi, G. Biostimulant activity of silicon in horticulture. Sci. Hortic. 2015, 196, 66-81. [CrossRef]

62. Hou, L.; Szwonek, E.; Xing, S. Advances in silicon research of horticultural crops. Veg. Crops Res. Bull. 2006, 64, 5-17.

63. Sacala, E.; Durbajlo, W. The effect of sodium silicate on maize growing under stress conditions. Przem. Chem. 2012, 91,949-951. (In Polish)

64. Adrees, M.; Ali, S.; Rizwan, M.; Zia-ur-Rehman, M.; Ibrahim, M.; Abbas, F.; Farid, M.; Qayyum, M.F.; Irshad, M.K. Mechanisms of silicon-mediated alleviation of heavy metal toxicity in plants: A review. Ecotoxicol. Environ. Saf. 2015, 119, 186-197. [CrossRef]

65. Pati, S.; Pal, B.; Badole, S.; Hazra, G.C.; Mandal, B. Effect of silicon fertilization on growth, yield, and nutrient uptake of rice. Commun. Soil Sci. Plant Anal. 2016, 47, 284-290. [CrossRef]

66. Mustafa, T.; Sattar, A.; Sher, A.; Ul-Allah, S.; Ijaz, M.; Irfan, M.; Buth, M.; Cheema, M. Exogenous application of silicon improves the performance of wheat under terminal heat stress by triggering physio-biochemical mechanisms. Sci. Rep. 2021, 11, 1-12 [CrossRef]

67. Etesami, H.; Jeong, B.R. Silicon (Si): Review and future prospects on the action mechanisms in alleviating biotic and abiotic stresses in plants. Ecotoxicol. Environ. Saf. 2018, 147, 881-896. [CrossRef]

68. Hussain, A.; Rizwan, M.; Ali, Q.; Shafaqat, A. Seed priming with silicon nanoparticles improved the biomass and yield while reduced the oxidative stress and cadmium concentration in wheat grains. Environ. Sci. Pollut. Res. 2019, 26, 7579-7588. [CrossRef]

69. Qados, A.M.A. Mechanism of nanosilicon-mediated alleviation of salinity stress in faba bean (Vicia faba L.) plants. J. Exp. Agric. Int. 2015, 7, 78-95. [CrossRef]

70. Saleh, J.; Najafi, N.; Oustan, S. Effects of silicon application on wheat growth and some physiological characteristics under different levels and sources of salinity. Commun. Soil Sci. Plant Anal. 2017, 48, 1114-1122. [CrossRef]

71. Chen, W.; Yao, X.; Cai, K.; Chen, J. Silicon alleviates drought stress of rice plants by improving plant water status, photosynthesis and mineral nutrient absorption. Biol. Trace Elem. Res. 2011, 142, 67-76. [CrossRef] 
72. Ali, S.; Farooq, M.A.; Yasmeen, T.; Hussain, S.; Arif, M.S.; Abbas, F.; Bharwana, S.A.; Zhang, G. The influence of silicon on barley growth, photosynthesis and ultra-structure under chromium stress. Ecotoxicol. Environ. Saf. 2013, 89, 66-72. [CrossRef]

73. Xie, Z.; Song, R.; Shao, H.; Song, F.; Xu, H.; Lu, Y. Silicon improves maize photosynthesis in saline-alkaline soils. Sci. World J. 2015, 2015, 245072. [CrossRef] [PubMed]

74. Zhang, W.J.; Zhang, X.J.; Lang, D.Y.; Li, M.; Liu, H.; Zhang, X.H. Silicon alleviates salt and drought stress of Glycyrrhiza uralensis plants by improving photosynthesis and water status. Biol. Plant. 2020, 64, 302-313. [CrossRef]

75. Ma, J.; Choi, H.; Stafford, R.J.; Miller, M.J. Silicone-specific imaging using an inversion-recovery-prepared fast three-point Dixon technique. J. Magn. Reson. Imaging 2004, 19, 298-302. [CrossRef]

76. Guével, M.H.; Menzies, J.G.; Bélanger, R.R. Effect of root and foliar applications of soluble silicon on powdery mildew control and growth of wheat plants. Eur. J. Plant Pathol. 2007, 119, 429-436. [CrossRef]

77. Artyszak, A. Effect of silicon fertilization on crop yield quantity and quality-A literature review in Europe. Plants 2018, 7, 54 [CrossRef] [PubMed]

78. De Oliveira, R.L.L.; de Mello Prado, R.; Felisberto, G.; Cruz, F.J.R. Different sources of silicon by foliar spraying on the growth and gas exchange in sorghum. J. Soil Sci. Plan. Nutr 2019, 19, 948-953. [CrossRef]

79. Grašič, M.; Dobravc, M.; Golob, A.; Vogel-Mikuš, K.; Gaberščik, A. Water shortage reduces silicon uptake in barley leaves. Agric. Water Manag. 2019, 217, 47-56. [CrossRef]

80. Domiciano, G.P.; Cacique, I.S.; Chagas Freitas, C.; Filippi, M.C.C.; da Matta, F.M.; do Vale, F.X.R.; Rodrigues, F.Á. Alterations in gas exchange and oxidative metabolism in rice leaves infected by Pyricularia oryzae are attenuated by silicon. Phytopathology 2015 105, 738-747. [CrossRef]

81. Laane, H.-M. The effects of foliar sprays with different silicon compounds. Plants 2018, 7, 45. [CrossRef]

82. Sienkiewicz-Cholewa, U. Response of spring wheat grown in drought stress to foliar and soil silicon application. Prog. Plant Prot. 2021, 61, 207-213. [CrossRef]

83. Abdel-Haliem, M.E.; Hegazy, H.S.; Hassan, N.S.; Naguib, D.M. Effect of silica ions and nano silica on rice plants under salinity stress. Ecol. Eng. 2017, 99, 282-289. [CrossRef]

84. Hellal, F.A.; Abdelhameid, M.; Abo-Basha, D.M.; Zewainy, R.M. Alleviation of the adverse effects of soil salinity stress by foliar application of silicon on faba bean (Vica faba L.). Res. J. Appl. Sci. 2012, 8, 4428-4433.

85. Shaaban, M.M.; Abou El-Nour, E.Z.A. Macro and micro-nutrients concentrations and uptake by maize seedlings irrigated with fresh or saline water as affected by K-silicate foliar fertilization. Am. J. Plant Physiol. 2014, 9, 95-102. [CrossRef]

86. Avestan, S.; Ghasemnezhad, M.; Esfahani, M.; Byrt, C.S. Application of nano-silicon dioxide improves salt stress tolerance in strawberry plants. Agronomy 2019, 9, 246. [CrossRef]

87. Qados, A.; Moftah, A. Influence of silicon and nano-silicon on germination, growth and yield of faba bean (Vicia faba L.) under salt stress conditions. J. Exp. Agric. Int. 2014, 5, 509-524. [CrossRef]

88. Maathuis, F.J.M.; Amtmann, A. $\mathrm{K}^{+}$nutrition and $\mathrm{Na}^{+}$toxicity: The basis of cellular $\mathrm{K}^{+} / \mathrm{Na}^{+}$ratios. Ann. Bot. 1999, 84, 123-133. [CrossRef]

89. Shabala, S.; Cuin, T.A. Potassium transport and plant salt tolerance. Physiol. Plant. 2008, 133, 651-669. [CrossRef] [PubMed]

90. Chakraborty, K.; Bhaduri, D.; Meena, H.N.; Kalariya, K. External potassium $\left(\mathrm{K}\left({ }^{+}\right)\right)$application improves salinity tolerance by promoting $\mathrm{Na}\left({ }^{+}\right)$-exclusion, $\mathrm{K}\left({ }^{+}\right)$-accumulation and osmotic adjustment in contrasting peanut cultivars. Plant Physiol. Biochem. 2016, 103, 143-153. [CrossRef]

91. Mittler, R. Oxidative stress, antioxidants and stress tolerance. Trends Plant Sci. 2002, 7, 405-410. [CrossRef]

92. Ozfidan-Konakci, C.; Yildiztugay, E.; Kucukoduk, M. Protective roles of exogenously applied gallic acid in Oryza sativa subjected to salt and osmotic stresses: Effects on the total antioxidant capacity. Plant Growth Regul. 2015, 75, 219-234. [CrossRef]

93. Tyerman, S.D.; Munns, R.; Fricke, W.; Arsova, B.; Barkla, B.J.; Bose, J.; Bramley, H.; Byrt, C.; Chen, Z.; Wen, Z. Energy costs of salinity tolerance in crop plants. New Phytol. 2019, 221, 25-29. [CrossRef] [PubMed]

94. Rodrigues-Corrêa, K.C.D.S.; Fett-Neto, A.G. Abiotic stresses and non-protein amino acids in plants. Crit. Rev. Plant Sci. 2019, 38, 411-430. [CrossRef]

95. Dawood, M.G.; Taie, H.A.A.; Nassar, R.M.A.; Abdelhamid, M.T.; Schmidhalter, U. The changes induced in the physiological, biochemical and anatomical characteristics of Vicia faba by the exogenous application of proline under seawater stress. S. Afr. J. Bot. 2014, 93, 54-63. [CrossRef]

96. Zeng, F.; Shabala, L.; Zhou, M.; Zhang, G.; Shabala, S. Barley responses to combined waterlogging and salinity stress: Separating effects of oxygen deprivation and elemental toxicity. Front. Plant Sci. 2013, 4, 313. [CrossRef]

97. Negrao, S.; Schmöckel, S.M.; Tester, M. Evaluating traits contributing to salinity tolerance. Ann. Bot. 2017, 119, 13-26. [CrossRef]

98. Taiz, L.; Zeiger, E. Photosynthesis: Physiological and Ecological Considerations. In Plant Physiology, 4th ed.; Taiz, L., Zeiger, E., Eds.; Sinauer Associates Inc.: Sunderland, MA, USA, 2002; Volume 9, pp. 172-174.

99. Zeeshan, M.; Lu, M.; Sehar, S.; Holford, P.; Wu, F. Comparison of biochemical, anatomical, morphological, and physiological responses to salinity stress in wheat and barley genotypes deferring in salinity tolerance. Agronomy 2020, 10, 127. [CrossRef]

100. Parida, A.K.; Das, A.B.; Mittra, B. Effects of $\mathrm{NaCl}$ stress on the structure, pigment complex composition, and photosynthetic activity of mangrove Bruguiera parviflora chloroplasts. Photosynthetica 2003, 41, 191-200. [CrossRef]

101. Kalteh, M.; Alipour, Z.; Ashraf, S.; Marashi Aliabadi, M.; Falah Nosratabadi, A. Effect of silica nanoparticles on basil (Ocimum basilicum) under salinity stress. J. Chem. Health Risks 2018, 4, 49-55. [CrossRef] 
102. Chung, Y.S.; Kim, K.S.; Hamayun, M.; Kim, Y. Silicon confers soybean resistance to salinity stress through regulation of reactive oxygen and reactive nitrogen species. Front. Plant Sci. 2020, 10, 1725. [CrossRef]

103. Mateos-Naranjo, E.; Andrades-Moreno, L.; Davy, A.J. Silicon alleviates deleterious effects of high salinity on the halophytic grass Spartina densiflora. Plant Physiol. Biochem. 2013, 63, 115-121. [CrossRef]

104. Ueda, A.; Yahagi, H.; Fujikawa, Y.; Nagaoka, T.; Esaka, M.; Calcaño, M.; González, M.M.; Martich, J.D.H.; Saneoka, H. Comparative physiological analysis of salinity tolerance in rice. Soil Sci. Plant Nutr. 2013, 59, 896-903. [CrossRef]

105. Ueda, A.; Kanechi, M.; Uno, Y.; Inagaki, N. Photosynthetic limitations of a halophyte sea aster (Aster tripolium L.) under water stress and $\mathrm{NaCl}$ stress. J. Plant Res. 2003, 116, 65-70. [CrossRef] [PubMed]

106. Hernández, J.A.; Olmos, E.; Corpas, F.J.; Sevilla, F.; del Río, L.A. Salt-induced oxidative stress in chloroplasts of pea plants. Plant Sci. 1995, 105, 151-167. [CrossRef]

107. Gururani, M.A.; Venkatesh, J.; Tran, L.S.P. Regulation of photosynthesis during abiotic stress-induced photoinhibition. Mol. Plant 2015, 8, 1304-1320. [CrossRef]

108. Ali, M.; Gul, A.; Hasan, H.; Gul, S.; Fareed, A.; Nadeem, M.; Siddique, R.; Jan, S.U.; Jamil, M. Cellular Mechanisms of Drought Tolerance in Wheat. In Climate Change and Food Security with Emphasis on Wheat; Oztruk, M., Gul, A., Eds.; Academic Press: Cambridge, MA, USA, 2020; Volume 9, pp. 155-164. [CrossRef]

109. Leegood, R.C.; Lea, P.J.; Adcock, M.D.; Häusler, R.E. The regulation and control of photorespiration. J. Exp. Bot. 1995, 46, 1397-1414. [CrossRef]

110. Netondo, G.W.; Onyango, J.C.; Beck, E. Sorghum and salinity: II. Gas exchange and chlorophyll fluorescence of sorghum under salt stress. Crop Sci. 2004, 44, 806. [CrossRef]

111. Sharma, N.; Gupta, N.K.; Gupta, S.; Hasegawa, H. Effect of $\mathrm{NaCl}$ salinity on photosynthetic rate, transpiration rate, and oxidative stress tolerance in contrasting wheat genotypes. Photosynthetica 2005, 43, 609-613. [CrossRef]

112. James, R.A.; Rivelli, A.R.; Munns, R.; von Caemmerer, S. Factors affecting $\mathrm{CO}_{2}$ assimilation, leaf injury and growth in salt-stressed durum wheat. Funct. Plant Biol. 2002, 29, 1393-1403. [CrossRef]

113. Yeo, A.R.; Flowers, S.A.; Rao, G.; Welfare, K.; Senanayake, N.; Flowers, T.J. Silicon reduces sodium uptake in rice (Oryza sativa L.) in saline conditions and this is accounted for by a reduction in the transpirational bypass flow. Plant Cell Environ. 1999, 22, 559-565. [CrossRef]

114. Li, H.; Zhu, Y.; Hu, Y. Beneficial effects of silicon in alleviating salinity stress of tomato seedlings grown under sand culture. Acta Physiol Plant 2015, 37, 71. [CrossRef]

115. Zhu, Y.; Gong, H. Beneficial effects of silicon on salt and drought tolerance in plants. Agron. Sustain. Dev. 2014, 34, 455-472. [CrossRef]

116. Rios, J.J.; Martínez-Ballesta, M.C.; Ruiz, J.M.; Blasco, B.; Carvajal, M. Silicon-mediated improvement in plant salinity tolerance: The role of aquaporins. Front. Plant Sci. 2017, 8, 948. [CrossRef]

117. Goltsev, V.; Zaharieva, I.; Chernev, P.; Kouzmanova, M.; Kalaji, H.M.; Yordanov, I.; Krasteva, V.; Alexandrov, V.; Stefanov, D.; Allakhverdiev, S.I. Drought-induced modifications of photosynthetic electron transport in intact leaves: Analysis and use of neural networks as a tool for a rapid non-invasive estimation. Biochim. Biophys. Acta BBA Bioenerg. 2012, 1817, 1490-1498. [CrossRef]

118. Brestic, M.; Zivcak, M. PSII Fluorescence Techniques for Measurement of Drought and High Temperature Stress Signal in Crop Plants: Protocols and Applications. In Molecular Stress Physiology of Plants; Rout, G.R., Das, A.B., Eds.; Springer: Cham, Germany, 2013; pp. 87-131. [CrossRef]

119. Kalaji, H.M.; Jajoo, A.; Oukarroum, A.; Brestic, M.; Zivcak, M.; Samborska, I.A.; Cetner, M.D.; Łukasik, I.; Goltsev, V.N.; Ladle, R.J. Chlorophyll a fluorescence as a tool to monitor physiological status of plants under abiotic stress conditions. Acta Physiol. Plant. 2016, 38, 102. [CrossRef]

120. Trawczyński, C. Wpływ dolistnego nawożenia preparatem Herbagreen na plonowanie ziemniaków/The effect of foliar fertilization with Herbagreen on potato yielding. Ziemn. Polski 2013, 2, 29-33. (In Polish)

121. Kumar, S.; Soukup, M.; Elbaum, R. Silicification in grasses: Variation between different cell types. Front. Plant Sci. 2017, 8, 438. [CrossRef]

122. Souri, Z.; Khanna, K.; Karimi, N.; Ahmad, P. Silicon and plants: Current knowledge and future prospects. J. Plant Growth Reg. 2021, 40, 906-925. [CrossRef]

123. Ibrahim, W.; Ahmed, I.M.; Chen, X.; Cao, F.; Zhu, S.; Wu, F. Genotypic differences in photosynthetic performance, antioxidant capacity, ultrastructure and nutrients in response to combined stress of salinity and Cd in cotton. BioMetals 2015, 28, 1063-1078. [CrossRef]

124. Xia, J.; Li, Y.; Zou, D. Effects of salinity stress on PSII in Ulva lactuca as probed by chlorophyll fluorescence measurements. Aquat. Bot. 2004, 80, 129-137. [CrossRef]

125. Choi, C.S.; Sano, H. Abiotic-stress induces demethylation and transcriptional activation of a gene encoding a glycerophosphodiesterase-like protein in tobacco plants. Mol. Genet. Genom. 2007, 277, 589-600. [CrossRef] [PubMed]

126. Finnegan, E.J.; Peacock, W.J.; Dennis, E.S. Reduced DNA methylation in Arabidopsis thaliana results in abnormal plant development. Proc. Natl. Acad. Sci. USA 1996, 93, 8449-8454. [CrossRef]

127. Mirouze, M.; Paszkowski, J. Epigenetic contribution to stress adaptation in plants. Curr. Opin. Plant Biol. 2011, 14, 267-274. [CrossRef] [PubMed] 
128. Sun, C.; Ali, K.; Yan, K.; Fiaz, S.; Dormatey, R.; Bi, Z.; Bai, J. Exploration of epigenetics for improvement of drought and other stress resistance in crops: A review. Plants 2021, 10, 1226. [CrossRef]

129. Doyle, J.J.; Doyle, J.L. Isolation of plant DNA from fresh tissue. Focus 1990, 12, 13-15.

130. Bassam, B.J.; Gresshoff, P.M. Silver staining DNA in polyacrylamide gels. Nat. Protoc. 2007, 2, 2649-2654. [CrossRef]

131. Walder, R.Y.; Langtimm, C.J.; Chaterjee, R.; Walder, J.A. Cloning of the MspI modification enzyme. The site of modification and its effect on cleavage by MspI and HpaII. J. Biol. Chem. 1983, 258, 1235-1241. [CrossRef]

132. Xiangqian, L.; Mingliang, X.; Schuyler, S.K. DNA methylation profiles differ between field- and in vitro-grown leaves of apple. J. Plant Physiol. 2002, 159, 1229-1234. [CrossRef] 